\title{
THE CHANGING OF THE RELATIONSHIPS BETWEEN CARBON FOOTPRINTS AND FINAL DEMAND: PANEL DATA EVIDENCE FOR 40 MAJOR COUNTRIES
}

\author{
Pablo-Romero, María del P. ${ }^{a}$ and Sánchez-Braza, Antonio ${ }^{\text {b }}$
}

\author{
a. Corresponding author \\ Economic Analysis Department \\ Facultad de CC. Económicas y Empresariales, University of Seville \\ Ramon y Cajal 1 \\ 41018 Seville, Spain \\ Telephone +34954557611 fax +34954557629 \\ Universidad Autónoma de Chile, Chile \\ mpablorom@us.es \\ b. Economic Analysis Department \\ Facultad de CC. Económicas y Empresariales, University of Seville \\ Ramon y Cajal 1 \\ 41018 Seville, Spain \\ Telephone +34954557529 fax +34954557629 \\ asb@us.es
}

\begin{abstract}
Global warming and environmental pollution have led many countries to begin to implement measures to reduce the use of fossil fuels. However, emissions reductions may have been reached because of the displacement of emissions intensive production. The objective of this study is to analyse the relationships between the emissions caused by countries from a demand point of view, the carbon footprints, and the demand for goods and services in these countries, and especially in the European countries. With this aim, a two-step process was carried out. Firstly, carbon footprints were calculated during the 1995-2009 period. Secondly, the EKC hypothesis between these carbon footprints and the total final demands were tested by using panel data and a multilevel mixed-effects model. The results show that the EKC hypothesis is not supported when considering carbon footprints with respect to domestic final demand. It is also shown that carbon footprints are slightly increasing with respect to final demand beyond proportionality. The carbon footprint elasticities are different between countries, their values increasing with the final demand per capita of countries.
\end{abstract}

Keywords: Carbon footprints; final demand; multilevel mixed-effects model

JEL Classification: C23, O44, O50, O52, Q56 


\section{THE CHANGING OF THE RELATIONSHIPS BETWEEN CARBON FOOTPRINTS AND FINAL DEMAND: PANEL DATA EVIDENCE FOR 40 MAJOR COUNTRIES}

\section{INTRODUCTION}

Today, the problems of global warming and environmental pollution have become major concerns among economists and environmentalists. Emissions of $\mathrm{CO}_{2}$ are considered to be the main contributor, causing problems on a global scale (Fodha and Zaghdoud, 2009; Lau et al. 2014), with the consumption of fossil fuels being the main cause of these emissions. This has led many countries to begin to implement measures to reduce the use of fossil fuels by promoting renewable energy and the application of energy efficiency measures, especially in developed countries. As a consequence, many of these countries, as stated in Kanemoto et al. (2014), have reduced their emissions, and some of them have even fulfilled their Kyoto Protocol $\mathrm{CO}_{2}$ reduction commitments.

Nevertheless, these countries may have achieved these commitments partly because they have displaced emissions intensive production offshore, in order to reduce costs on environmental controls (Lau et al., 2014). Therefore, polluting industries and businesses have tended to be displaced to developing countries, where environmental standards are relatively low, making the shifting of $\mathrm{CO}_{2}$ emissions from developed to developing countries a growing problem. Hoekstra et al. (2016) and Malik and Lan (2016) show explicitly that outsourcing occurs predominantly between developed and developing countries. Additionally, Malik et al. (2016) also investigate the geographical bilateral relationships and the commodity content of outsourcing. In some other studies, such as those by Aichele and Felbermayr (2012) and Andrew et al. (2013), it is estimated that around $30 \%$ of global emissions are linked to production for export, enlarging the discrepancy between the national emissions and their 
carbon footprints. Moreover, Kanemoto et al. (2014) verify that emissions from developed countries increase when adjusting for trade. They find that the sectors lowering their domestic emissions are often those that are increasing their imports of embodied $\mathrm{CO}_{2}$, which suggests a burden shifting of the same emissions-intensive activities, and not cleaner production patterns.

In light of this, the analyses made by many researchers studying the environmental Kuznets curve (EKC) hypothesis, when exploring the relationship between GDP, energy consumption and carbon emissions in different countries and regions, may become meaningless from a global point of view. The EKC hypothesis states that the increase in income of a country will increase its pollution until a certain point of economic development, at which time the relationship between both variables becomes negative, which may be attributed to the availability of more technologies that improve energy efficiency, energy saving and renewable energy (Al-Mulali et al., 2015a). Nevertheless, the EKC hypothesis may be verified in a country, at least partially, by displacing emissions-intensive activities, without in fact reducing emissions linked to production. The increased displacement of emissionsintensive activities may be related to international trade development, leading some economists, such as Jebli et al. (2016), to include trade as a control variable when testing the EKC hypothesis. Nevertheless, these studies refer to emissions that have been generated within a country and they do not allow for what is happening behind borders.

The objective of this study is to analyze the relationships between the emissions caused by countries from a demand point of view, the carbon footprints, and the demand for goods and services in these countries, and especially in the European countries. Considering carbon footprints and final demand, rather than the $\mathrm{CO}_{2}$ emissions and GDP (as most often used in other studies when estimating the EKC), allows us to relate the generated emissions with the ultimate purpose of production activities. The carbon footprints that refer to the cumulated $\mathrm{CO}_{2}$ emissions through a supply chain, or through the life cycle of a product, may correctly attribute the emission sources to consumption activities (Hertwich and Peters, 2009). 
Therefore, the use of carbon footprints and final demand provides a different perspective on the drivers of emissions at the global level. Thus, while the traditional focus on the emission sources may be useful for compiling statistics and understanding the global carbon cycle, it is considered insufficient to design mitigation policy (Peters et al., 2009). Although supply-side measures, such as technological improvements and renewable energies use, have been reducing emissions, they are not enough to keep emissions at sustainable levels, as stated by Malik et al. (2016). Therefore, demand side measures, or at least knowing how emissions change with this demand, are also necessary to better implement energy and environmental policies oriented to reducing global carbon emissions.

With this aim, a two-step process was carried out. Firstly, carbon footprints were calculated. The global multi-regional input-output database (MRIO), the World Input-Output Database (Dietzenbacher et al., 2013; Timmer et al., 2015; WIOD, 2015) and the approaches of Serrano and Dietzenbacher (2010) and Rueda-Cantuche (2012) were used. Data from the WIOD database refer to the period 1995-2009 and to forty countries worldwide, including the major economies in the world, covering about $85 \%$ of world GDP in 2008 (at current exchange rates). These countries are, all 27 members of the EU, Australia, Brazil, Canada, China, India, Indonesia, Japan, Mexico, Russia, South Korea, Taiwan, Turkey and the USA.

Secondly, this study tests the EKC hypothesis where the carbon footprint is the dependent variable and the total final demand is the independent variable, by using panel data techniques referring to the same forty countries and period. The EKC hypothesis was tested taking into account the methodological heterogeneity problems of panel data, which have been highlighted in some previous studies, such as that by Piaggio and Padilla (2012). For that reason, two control variables were included. The first refers to the economic structure of each country, as in previous studies, such as those of Perrings and Ansuategi (2000) and Friedl and Getzner (2003). The second refers to imports, as have been included in previous studies, such 
as that of Al-Mulali et al. (2015b). Additionally, the EKC was estimated by using a multilevel mixed-effects model which allows flexibility to be added to the estimated function (RabeHesketh and Skrondal, 2008; West and Galecki, 2011; Leckie, et al., 2014).

Finally, from the EKC estimates, the elasticity of carbon footprints with respect to total demand was calculated for each year and country. This allowed it to be determined whether, and to what extent, a percentage variation in final demand leads to relative changes in emissions generated by countries, analyzing whether there is a different behavior between countries. These elasticities were calculated following Pablo-Romero and Sánchez-Braza (2015).

The paper is organized as follows. The methodology is explained in Section 2. Section 3 specifies the statistical information sources used. In Section 4, the results of the carbon footprints and the EKC estimates are presented, together with the values of the elasticities calculated from these estimates. Additionally, a discussion and policy implications of the main results are provided in Section 5. Finally, the conclusions of this paper are given in Section 6.

\section{METHODOLOGY}

The economic analysis made in this study combined the use of two different methodologies. On the one hand, the carbon footprints were calculated within a multiregional framework. On the other hand, the carbon footprints were related to final demand with the aim of testing the EKC hypothesis. Moreover, the household final demand and total final demand were considered in this study to compare the EKC. 


\subsection{Carbon footprint and total emissions generated by countries}

The starting point was the MRIO table at basic prices, which describes the flow of goods and services from all sectors to all intermediate and final recipients. MRIO tables have been widely used to calculate carbon footprints and to analyze the environmental consequences of international trade. Among these studies it is worth mentioning those by Wiedmann (2009), Wiedmann et al., (2010), Wiebe et al., (2012), Zhang et al., (2013), Kanemoto et al., (2014) and Tang et al., (2015).

Alternative MRIO databases have been used in previous studies, such as EXIOBASE (Tukker et al. 2013), GTAP (Peters et al. 2011; Andrew and Peters 2013), IDE-JETRO (Meng et al. 2013), Eora (Lenzen et al. 2012; Lenzen et al. 2013) and WIOD (Dietzenbacher et al., 2013; Timmer et al., 2015; WIOD, 2015). In this study, the WIOD MRIO table, which refers to forty countries, was used. Each of these countries have economic activities classified into $n$ industries (35 in this case), and may differ in production technologies and/or emission levels per unit of production.

The Leontief quantity model may be expressed according to Serrano and Dietzenbacher (2010), as $x=\mathbf{A} x+y$ or:

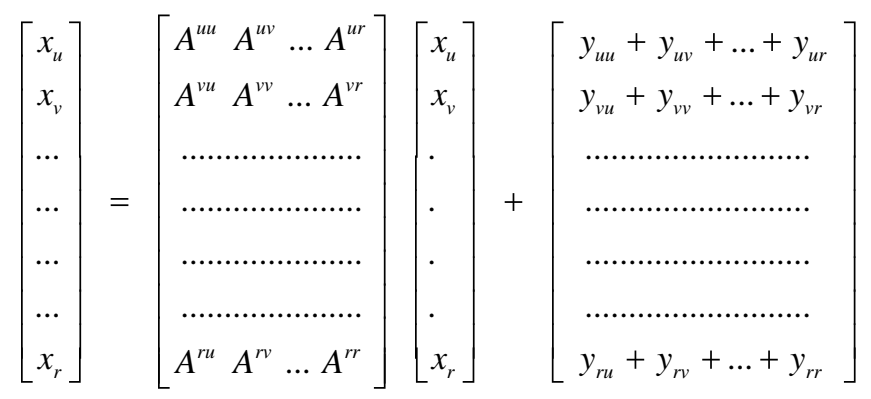

where

$u=$ country $1, v=$ country $2, \ldots, r=$ rest of the world $(r w)$.

$A^{u u}, A^{v v}, \ldots, A^{r r}=$ matrices of domestic technical coefficients of countries $u, v, \ldots$ and $r w$ $A^{u v}, \ldots, A^{u r}, A^{v u}, \ldots, A^{v r}, A^{r u}=$ matrices of imported input coefficients between countries. 
$y_{u u}, y_{v v}, \ldots, y_{r r}=$ final domestic demand of countries $u, v, .$. and $r w$

$y_{\mathrm{uv}}, \ldots, y_{\mathrm{ur}}, y_{\mathrm{vu}}, \ldots, y_{\mathrm{vr}}, y_{\mathrm{ru}}, \ldots=$ final external demand of each country to each of the remaining countries.

$x_{\mathrm{u}}, x_{\mathrm{v}}, \ldots x_{\mathrm{r}}=$ total industry outputs.

The solution to the Leontief system is:

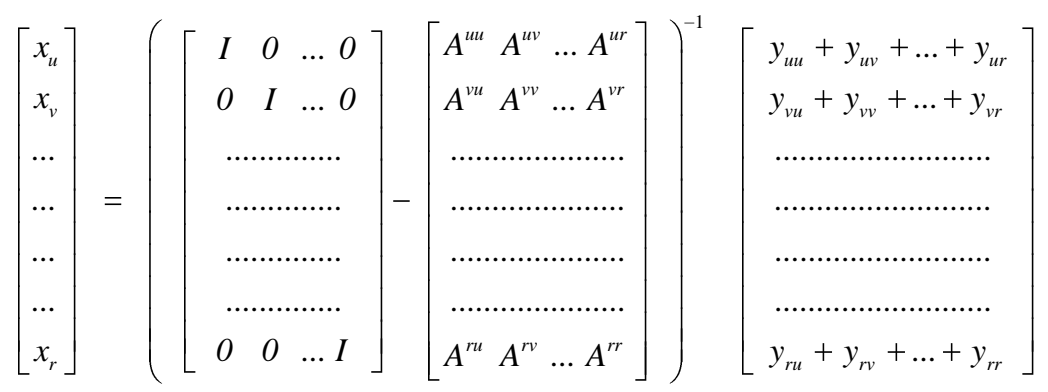

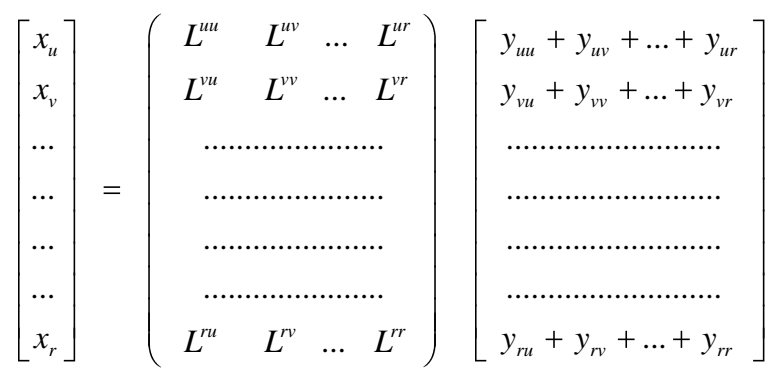

The vector of total emissions produced in each country $\left(w_{u}, w_{v}, \ldots, w_{r}\right)$, is given by:

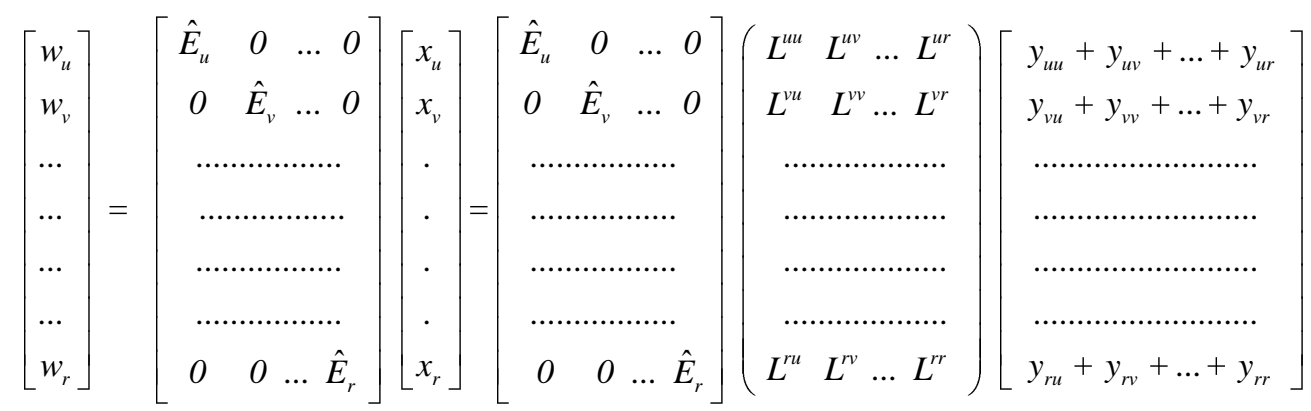

where, $\mathrm{e}_{u}, \mathrm{e}_{v}, \ldots, \mathrm{e}_{r}=$ emissions per unit of production of countries $u, v, . ., r w$. These vectors are of order 35 (number of sectors). According to Rueda-Cantuche (2012), this vector may be properly extended as: 

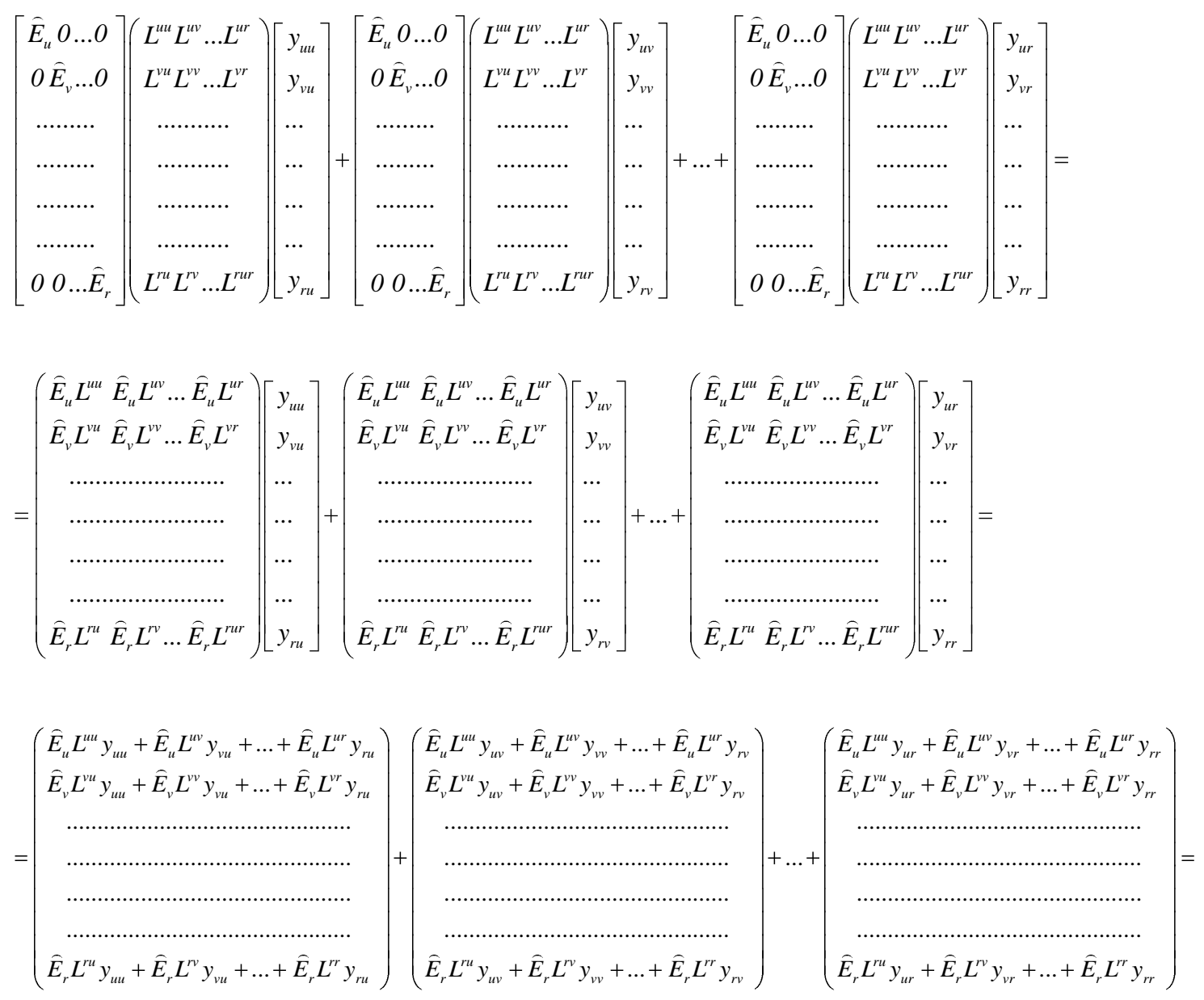

$$
=\left[\begin{array}{c}
w_{u u} \\
w_{v u} \\
\ldots \\
\ldots \\
\ldots \\
\ldots \\
w_{r u}
\end{array}\right]+\left[\begin{array}{c}
w_{u v} \\
w_{v v} \\
\ldots \\
\ldots \\
\ldots \\
\ldots \\
w_{r v}
\end{array}\right]+\ldots+\left[\begin{array}{c}
w_{u r} \\
w_{v r} \\
\ldots \\
\ldots \\
\ldots \\
\ldots \\
w_{r r}
\end{array}\right]=\left[\begin{array}{c}
w_{u} \\
w_{v} \\
\ldots \\
\ldots \\
\ldots \\
\ldots \\
w_{r}
\end{array}\right]
$$

Therefore, the carbon footprint of country $u$ (and similarly of other countries) may be obtained as:

$$
w f_{u}=w_{u u}+w_{v u}+\ldots+w_{r u}
$$

where:

$w_{u u}=$ emissions produced in country $u$, derived from the final demand of domestically produced commodities in country $u$, plus the emissions produced in country $u$ for the production of an exported commodity that will be used by another country to produce something else that country $u$ will import. 
$w_{v u}$ and $w_{r u}=$ emissions produced in country $v$ or $r$ derived from the imports needed to satisfy the final demand for domestically produced commodities of country $u$, plus the emissions produced in the countries $v$ or $r$ to satisfy the final demand for foreign commodities of country $u$.

Therefore, the carbon footprints allow assessing the emissions that have been generated anywhere in the world throughout the whole production process, in order to satisfy the demand for goods and services by residents in a country. Thus, the use of these carbon footprints allows the analysis of environmental issues from a demand point of view. Instead of carbon footprints, traditional measures of environmental pollution assess the emissions generated in the country in which goods and services are produced, regardless of who demands them. Therefore, these traditional measures analyze environmental problems from a production point of view. In this regard, Malik et al. (2016) stated that although the literature on environmental policies recommends developing demand and supply side measures for achieving emission reductions, there is a near absence of demand-side measures while supply side measures proliferate and are already exploited.

\subsection{The relationships between emissions generated by countries and their final demand}

In this study, the relationships between carbon footprint by countries and their final demand were analyzed by testing the EKC hypothesis between both variables in per capita terms. Similarly, this study also considered the relationships between the carbon footprints with respect to household final demand.

The general specification model for testing these different EKCs is expressed as follows:

$$
E_{i t}=A_{i t}+\beta_{1} Y_{i t}+\beta_{2} Y_{i t}^{2}+\beta_{3} Y_{i t}^{3}+e_{i t}
$$

where $E$ is a measure of emissions per capita, in this case carbon footprints, $Y$ is the independent variable of final demand per capita, $A$ represents the sum of the time effect and country or individual effect and $i$ and $t$ denote countries and years, respectively. Finally, $e$ is a 
random error term. Alternatively, as in some previous studies, environmental indicators have also been taken in absolute terms to reflect total human pressure (Luzzati and Orisini, 2009); in this study, absolute carbon footprints are additionally used to test the EKC hypothesis.

To properly estimate the functions and avoid multicollinearity problems between the $Y$ variable and its squared and cubic values, as noted in previous studies such as in Narayan and Narayan (2010), the data were converted to deviations from the geometric mean of the sample. Likewise, in order to avoid spurious estimates, the data have also been transformed into first differences, as in Pablo-Romero and Sánchez-Braza (2015). Using italics to indicate these deviations, and the symbol $\Delta$ to indicate first differences, it is possible to rewrite [1], as follows,

$\Delta \bar{E}_{i t}=\Delta \bar{A}_{i t}+\beta_{1} \Delta \bar{Y}_{i t}+\beta_{2} \Delta \bar{Y}_{i t}^{2}+\beta_{3} \Delta \bar{Y}_{i t}^{3}+e_{i t}$

where $\Delta \bar{A}_{i t}=\delta_{\mathrm{t}}$.

Similarly, [2] was estimated taking into account, or not, the cubic term of the variable $Y$. Previous estimates have sometimes used quadratic functions, as in Grossman and Krueger (1991) and Selden and Song (1994), and at other times used cubic functions, as in Luzzati and Orsini (2009), He and Richard (2010) and Ahmed and Long (2012).

The estimated $\beta$ coefficients inform about the relationships between the variables. If all $\beta$ coefficients are positive, then an increasing relationship exists between $E$ and $Y$. However, if the sign of the coefficients vary between them, different relationships exist, as indicated in Dinda (2004). The EKC exists if $\beta_{1}>0, \beta_{2}<0$ and $\beta_{3} \leq 0$. In this case, the turning points of the EKC hold where the carbon footprint elasticity, with respect to $Y$, is equal to zero.

From the estimated coefficients, the elasticity of $E$ with respect to $Y$ for each year and country may be calculated, allowing the possibility of different behavior between countries to be analyzed. Nevertheless, the behavior of different countries is exclusively linked to the final demand levels of the different countries, as the estimated coefficients $\beta_{1}, \beta_{2}$ and $\beta_{3}$ are 
constants. In this sense, some authors, such as Piaggio and Padilla (2012), have questioned the suitability of assuming the same functional form and parameters across countries, due to the heterogeneity of the sample. Thus, when estimating function, it is useful to take into account the heterogeneity that exists, or may exist, between countries, which means that $\beta$ coefficients may vary between countries.

In order to take into account the heterogeneity between countries, two options may be considered. The first is to test the EKC at national level (Song et al., 2008; Halicioglu, 2009; Menyah and Wolde-Rufael, 2010; Jalil and Feridun, 2011). However, as stated in Hsiao (2007), this option has less capacity for capturing the complexity of the behavior of the economies. The second option is to take the whole panel data sample, which include all countries, and allow the coefficients not to be constant, but to vary. By using this option, more degrees of freedom and more sample variability are achieved, improving the efficiency of econometric estimates (Hsiao et al., 1995).

Following the second option (see Appendix), if $\beta_{1}$ is defined as follows:

$\beta_{1}=\gamma_{1}+\sum_{n} \gamma_{1 n} Z_{i t}$

Then, equation [2] may be defined as:

$\overline{\Delta E}_{i t}=\Delta \bar{A}_{i t}+\gamma_{i} \Delta \bar{Y}_{i t}+\gamma_{1 s} \Delta \overline{S_{i t} Y_{i t}}+\gamma_{1 Q} \Delta \overline{Q_{i t} Y_{i t}}+\beta_{2} \Delta \bar{Y}_{i t}^{2}+\beta_{3} \Delta \bar{Y}_{i t}^{3}+e_{i t}$

$Z$ is a set of control variables that may affect the relationships between final demand and carbon footprints. Several control variables have been used in previous studies in the EKC estimates as economic structure (Perrings and Ansuategi, 2000; Friedl and Getzner, 2003), trade openness or alternatively exports or imports (Halicioglu, 2009, Jalil and Feridun, 2011, Ozturk and Acaravci, 2013, and Onafowora and Owoye, 2014; Al-Mulali et al., 2015b). In this study, two control variables are included: economic structure $(S)$ and imports $(Q) . S$ is measured as the percentage of industrial goods final demand, with respect to total final 
demand. $Q$ is measured as the percentage of imports related to total production. Both variables were included in the study as they may be related to carbon footprints, and these are generated by the production of goods and services demanded. In this regard, the footprints may be affected by the type of goods and services demanded and by country import volume, taking into account that some countries tend to reduce their national emissions by displacing their most polluting industries (Peters et al., 2012; Steckel et al., 2013; and Pablo-Romero and Sanchez-Braza, 2015).

As an alternative to the defined model, it is possible to define a more flexible model by including a random term in the $\beta_{1}$ and $\beta_{2}$ coefficients. Thus, equation [4] may be expressed as $\Delta \bar{E}_{i t}=\Delta \bar{A}_{i t}+\gamma_{i} \Delta \bar{Y}_{i t}+\gamma_{1 s} \Delta \overline{S_{i t} Y_{i t}}+\gamma_{1 Q} \Delta \overline{Q_{i t} Y_{i t}}+\mu_{1 i} \Delta \bar{Y}_{i t}+\gamma_{2} \Delta \bar{Y}_{i t}^{2}+\mu_{2 i} \Delta \bar{Y}_{i t}^{2}+\beta_{3} \Delta \bar{Y}_{i t}^{3}+e_{i t}$

where $\mu$ represents the random effects for the individual observations and $\beta_{1}$ and $\beta_{2}$ are defined as follows:

$$
\begin{aligned}
& \beta_{1}=b_{1 i}+\sum_{n} \gamma_{1 n} Z_{i t} \\
& b_{1 i}=\gamma_{1}+\mu_{1 i} \\
& \beta_{2 i}=\gamma_{2}+\mu_{2 i}
\end{aligned}
$$

The equation [5] may be estimated by using multilevel mixed-effects models (Rabe-Hesketh and Skrondal, 2008; West and Galecki, 2011; and Leckie et al., 2014).

From [5], the elasticity of $E$ with respect to $Y$ may be calculated for each year and country, as follows:

$$
e l a_{i t}=\gamma_{i t}+\mu_{1 i}+\gamma_{1 s} \bar{S}_{i t}+\gamma_{1 Q} \bar{Q}_{i t}+2 \gamma_{2} \bar{Y}_{i t}+2 \mu_{2 i} \bar{Y}_{i t}+3 \beta_{3} \bar{Y}_{i t}^{2}
$$

Several equations have been estimated in order to compare the results with different specification models. Table 1 displays the 40 different models and corresponding variables used to estimate the EKC that relates carbon footprints and final demand. 
Table 1. Models and variables used.

\begin{tabular}{|c|c|c|c|c|c|c|c|c|c|c|}
\hline Sample & $\begin{array}{c}E q \\
\text { number }\end{array}$ & & $Y($ per capita $)$ & $Y^{2}$ & $Y^{3}$ & $Q Y$ & $S Y$ & $\mu_{1} Y$ & $\mu_{2} Y^{2}$ & $N$. \\
\hline \multirow{20}{*}{$\begin{array}{c}\text { World } \\
\text { (40 countries) }\end{array}$} & \multirow{8}{*}{ [2] } & \multirow{4}{*}{$\begin{array}{l}\text { Carbon } \\
\text { Footprints } \\
\text { Per Capita (Ep) }\end{array}$} & \multirow{2}{*}{ Final Demand (TDp) } & \multirow{4}{*}{ yes } & no & no & no & no & no & 1 \\
\hline & & & & & yes & no & no & no & no & 2 \\
\hline & & & \multirow{2}{*}{$\begin{array}{l}\text { Final consumption } \\
\text { expenditure by } \\
\text { households (HDp) }\end{array}$} & & no & no & no & no & no & 3 \\
\hline & & & & & yes & no & no & no & no & 4 \\
\hline & & \multirow{4}{*}{$\begin{array}{l}\text { Carbon } \\
\text { Footprints } \\
\text { Absolute } \\
\text { (E) }\end{array}$} & \multirow{2}{*}{ Final Demand (TDp) } & \multirow{4}{*}{ yes } & no & no & no & no & no & 5 \\
\hline & & & & & yes & no & no & no & no & 6 \\
\hline & & & \multirow{2}{*}{$\begin{array}{l}\text { Final consumption } \\
\text { expenditure by } \\
\text { households (HDp) }\end{array}$} & & no & no & no & no & no & 7 \\
\hline & & & & & yes & no & no & no & no & 8 \\
\hline & \multirow{8}{*}{ [4] } & \multirow{4}{*}{$\begin{array}{l}\text { Carbon } \\
\text { Footprints } \\
\text { Per Capita } \\
\text { (Ep) } \\
\end{array}$} & \multirow{4}{*}{ Final Demand (TDp) } & \multirow{4}{*}{ yes } & no & yes & yes & no & no & 9 \\
\hline & & & & & no & yes & no & no & no & 10 \\
\hline & & & & & yes & yes & yes & no & no & 11 \\
\hline & & & & & yes & yes & no & no & no & 12 \\
\hline & & \multirow{4}{*}{$\begin{array}{l}\text { Carbon } \\
\text { Footprints } \\
\text { Absolute } \\
(\mathbf{E})\end{array}$} & \multirow{4}{*}{ Final Demand (TDp) } & \multirow{4}{*}{ yes } & no & yes & yes & no & no & 13 \\
\hline & & & & & no & yes & no & no & no & 14 \\
\hline & & & & & yes & yes & yes & no & no & 15 \\
\hline & & & & & yes & yes & no & no & no & 16 \\
\hline & \multirow{4}{*}{ [5] } & \multirow{2}{*}{$\begin{array}{l}\text { Carbon } \\
\text { Footprints } \\
\text { Per Capita } \\
\text { (Ep) } \\
\end{array}$} & \multirow{2}{*}{ Final Demand (TDp) } & \multirow{2}{*}{ yes } & no & yes & no & yes & no & 17 \\
\hline & & & & & no & yes & no & yes & yes & 18 \\
\hline & & \multirow{2}{*}{$\begin{array}{l}\text { Carbon } \\
\text { Footprints } \\
\text { Absolute } \\
(\mathbf{E})\end{array}$} & & & no & yes & no & yes & no & 19 \\
\hline & & & Final Demand (TDp) & yes & no & yes & no & yes & yes & 20 \\
\hline & & & Final Demand (TDp) & & no & no & no & no & no & 21 \\
\hline & & Footprints & 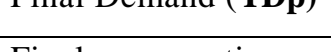 & & yes & no & no & no & no & 22 \\
\hline & & Per Capita & Final consumption & yes & no & no & no & no & no & 23 \\
\hline & {$[2]$} & $(\mathbf{E p})$ & $\begin{array}{l}\text { expenditure by } \\
\text { households (HDp) }\end{array}$ & & yes & no & no & no & no & 24 \\
\hline & {$[2]$} & & Final Demand (TDp) & & no & no & no & no & no & 25 \\
\hline & & Footprints & (1) & & yes & no & no & no & no & 26 \\
\hline & & Absolute & Final consumption & yes & no & no & no & no & no & 27 \\
\hline & & (E) & $\begin{array}{l}\text { expenditure by } \\
\text { households (HDp) }\end{array}$ & & yes & no & no & no & no & 28 \\
\hline & & Carbon & & & no & yes & yes & no & no & 29 \\
\hline Europe & & Footprints & Final Demand (TDp) & yes & no & yes & no & no & no & 30 \\
\hline (27 countries) & & Per Capita & & yes & yes & yes & yes & no & no & 31 \\
\hline & [4] & $(\mathbf{E p})$ & & & yes & yes & no & no & no & 32 \\
\hline & & Carbon & & & no & yes & yes & no & no & 33 \\
\hline & & Footprints & Final Demand (TDp) & yes & no & yes & no & no & no & 34 \\
\hline & & Absolute & ? & 90s & yes & yes & yes & no & no & 35 \\
\hline & & (E) & & & yes & yes & no & no & no & 36 \\
\hline & & Carbon & & & no & yes & no & yes & no & 37 \\
\hline & [5] & $\begin{array}{l}\text { Footprints } \\
\text { Per Capita } \\
\text { (Ep) }\end{array}$ & Final Demand (TDp) & yes & no & yes & no & yes & yes & 38 \\
\hline & & Carbon & & & no & yes & no & yes & no & 39 \\
\hline & & $\begin{array}{l}\text { Footprints } \\
\text { Absolute (E) }\end{array}$ & Final Demand (TDp) & yes & no & yes & no & yes & yes & 40 \\
\hline
\end{tabular}

The methodological innovations involved in these estimates may be summarized in two lines. Firstly, to our knowledge, it is the first time that carbon footprints have been 
calculated by using MRIO and final demand to estimate the EKC. The use of these measures, instead of the traditional ones, allows assessing the environmental issues from a demand point of view instead of the production point of view. Secondly, there are several methodological innovations when estimating the EKC. Among them, deviations from the geometric mean of the sample are used in order to avoid multicollinearity problems. Likewise, to take into account the heterogeneity between countries, panel data estimates have been performed allowing the coefficients not to be constant, thereby improving their efficiency. Additionally, random terms in the coefficients have been included to define a more flexible model, which have been estimated by using multilevel mixed-effects models. Finally, the carbon footprints elasticities, with respect to final demand, have been calculated for each year and country, allowing the analysis of different behaviors between countries.

\section{DATA}

The main source used was the World Input-Output Database (WIOD) (2015) presented in Dietzenbacher et al. (2013) and Timmer et al. (2015). The WIOD is divided into four large data groups, or sub-bases, for each considered country: World Input-Output Tables, National Input-Output Tables, Socio-Economic Accounts and Environmental Accounts. From this database, the sub-bases World Input-Output Tables and Environmental Accounts were used. All sub-bases contain time-series of data for forty countries worldwide, for the period from 1995 to 2011. These countries included the major economies in the world, covering about $85 \%$ of world GDP in 2008 (at current exchange rates). These countries are, all 27 members of the EU, Australia, Brazil, Canada, China, India, Indonesia, Japan, Mexico, Russia, South Korea, Taiwan, Turkey and the USA. 


\subsection{World Input-Output Tables}

The world input-output tables (WIOTs) are a set of national input-output tables that are connected with each other by bilateral international trade flows. It provides a comprehensive summary of all transactions in the global economy between industries and final users across countries. The columns contain information on production processes. Products can be used as intermediates by other industries, or as final products by households, governments (consumption) or companies (stocks and gross fixed capital formation). The gross output of each industry is equal to the sum of all uses of the output from that industry. The WIOTs have an industry by industry format. They provide details for 35 industries, covering the overall economy. In this study, the WIOTS from 1995 to 2009 were used to calculate the emissions footprints.

\subsection{Carbon Emissions}

The information about carbon emissions comes from the WIOD Environmental Accounts database presented in Genty (2012). This sub-base provides data for the 40 countries over the period from 1995 to 2009 . Total intermediate consumption emissions were used to calculate the footprint, while final consumption expenditure by household were used to measure the emissions directly derived from the use of goods and services by households. These variables are expressed in Kilotons (kt) and converted into natural logarithms.

\subsection{Final Demand}

The information about the final demand was calculated from the WIOTs, by adding columns 37 to 42 for each country and year (1995-2009) for each of the 35 sectors. These columns contain data about: Final consumption expenditure by households (37), Final consumption expenditure by non-profit organizations serving households (38), Final consumption expenditure by government (39), Gross fixed capital formation (41) and Changes in inventories and valuables (42). Final demand for each of the 35 sectors is considered for 
calculating the carbon footprints. Nevertheless, the aggregate value of final demand (as the sum of the values of the 35 sectors) have also been calculated in order to determine the total final demand by country and year. This aggregated value has been used in the EKC estimates. The figures were considered in thousands of constant 1995 US Dollars and converted into natural logarithms. The figures were corrected for the corresponding exchange rates.

\subsection{Population, structure and imports}

Information about population comes from the Penn World Table 7.1. (Heston et al., 2012). Figures are expressed in thousands and converted into natural logarithms. Structure is measured as the percentage of industrial goods final demand over total final demand. The information about this variable comes from the National Input-Output Tables (WIOD, 2015). Imports are measured as the percentage of total imports (sum of imports from all sectors) over total Output. The information about this variable also comes from the National Input-Output Tables (WIOD, 2015).

\section{RESULTS}

\subsection{Carbon footprints generated by countries}

Figure 1 shows the evolution of carbon footprints in absolute terms by country (represented by lines of different colors), from 1995 to 2009, for the 40 countries that make up the whole sample. The graph on the left side shows the evolution of carbon footprints for the EU-27 average value (in a dotted black line) and for each one of the rest of the sample countries. The values are spread around the thick black line that represents each year's sample average value (40 countries). The graph on the right side shows the evolution of carbon footprints for the 27 member countries of the EU. In this case, the thick black line represents each year's average value for the EU-27 countries. 
Both graphs show that carbon footprints in absolute terms have a slight upward trend over the analyzed period, although in the last two years it decreases in most countries, which may be related to the financial crisis observed in those years. On the graph on the left, it can be observed how two countries, the USA and China, clearly stand out in the upper plots, while three countries (on the right graph), Malta, Luxembourg and Cyprus, clearly stand out in the lower plots. Thus, as expected, the size of the country appears to be a determinant in the level of carbon footprints in absolute terms.

Figure 2 shows the evolution of carbon footprints in per capita terms. In this case, a slight increasing trend continues, which becomes more pronounced in recent years, especially in some countries. However, in the last two years shown, this trend was plainly decreasing in most countries, which may be related to the financial crisis as commented before. Significant differences between countries are again shown in Figure 2. Thus, it can be noted that the countries below the average trend (in both graphs in Figure 2) show a much steeper upward trend. Among the countries in the lower plots are India, Indonesia and Brazil (on the left graph). The first two even registered negative per capita values for the initial years of the sample, this being possible because values are converted into natural logarithms. Alongside these countries are China, Turkey and Mexico, which also have considerably low values, close to unity and even below in some years. Interestingly, China stands out as one of the countries with higher levels of carbon footprint in absolute terms, while it appears in the lower plots in carbon footprint per capita. The opposite occurs in the case of Luxembourg, which is among the countries with lower absolute values and higher per capita values (on the right graph). In these upper plots, the USA and Australia are highlighted as the countries with higher per capita footprint. In the case of the USA, it is the country with the highest level of carbon footprint in both absolute and per capita terms. In the case of the EU-27, Lithuania, Latvia, Bulgaria and Romania are distinguished by the lower per capita value plots, while Luxembourg, Finland and Greece, among others, detach from the higher plots. Finally, it is 
worth noting that each year's average value for the EU-27 countries is similar to the average value for the world sample (the dotted black line is above the thick black line on the left graph).

Figure 1. Evolution of carbon footprints in absolute terms (1995-2009).

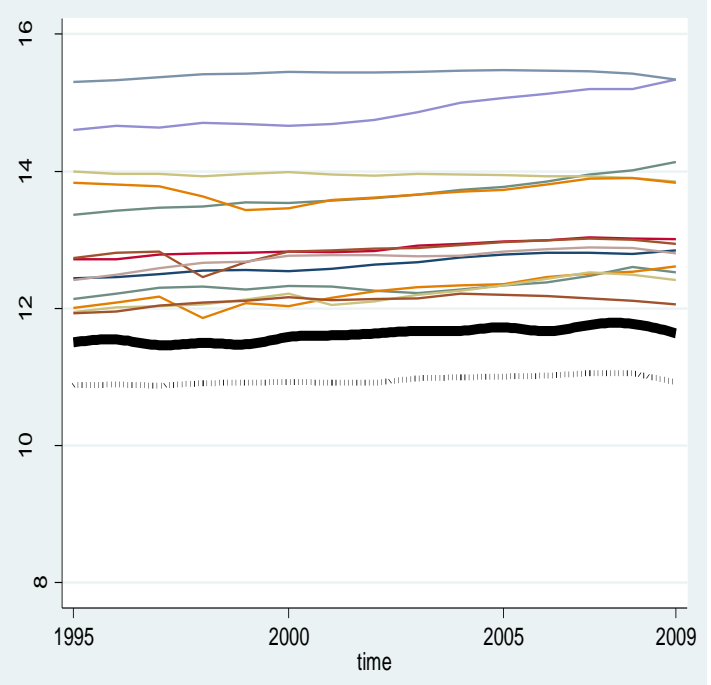

Whole sample (with EU-27 average)

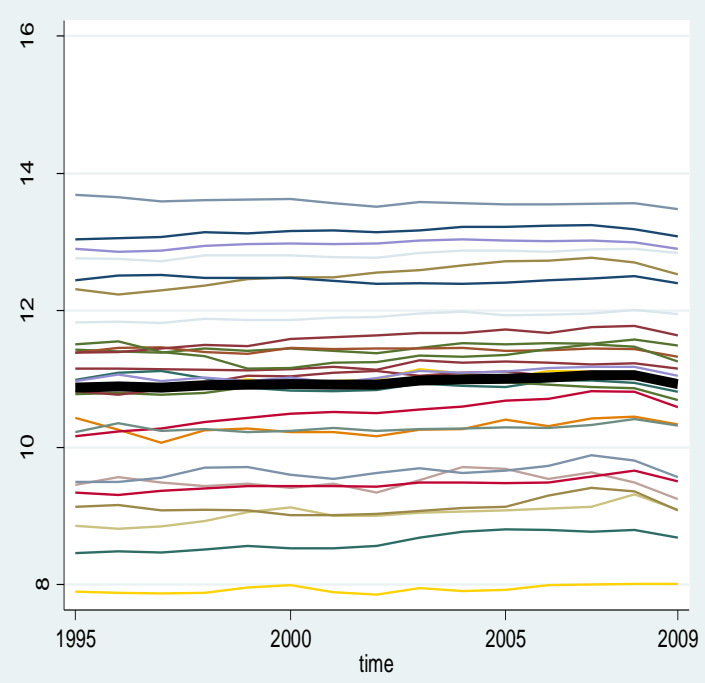

EU-27 countries

Figure 2. Evolution of carbon footprint emissions in per capita terms (1995-2009).

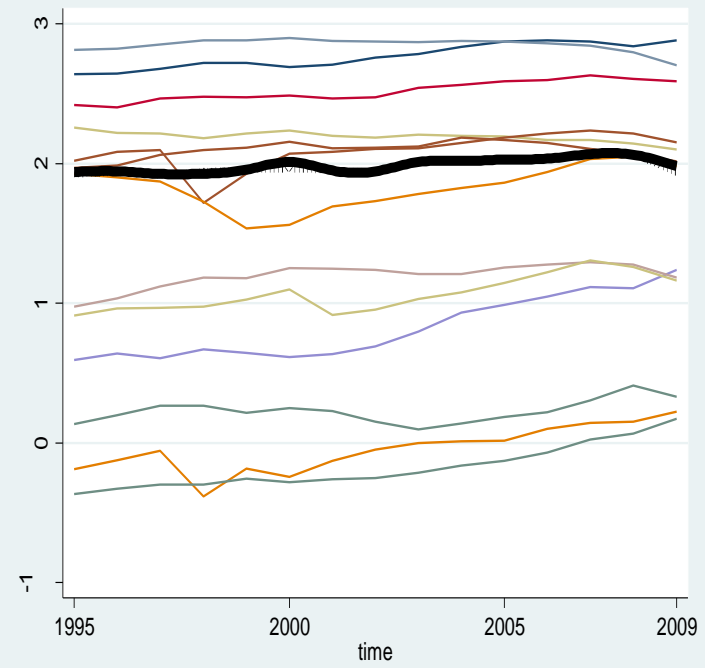

Whole sample (with EU-27 average)

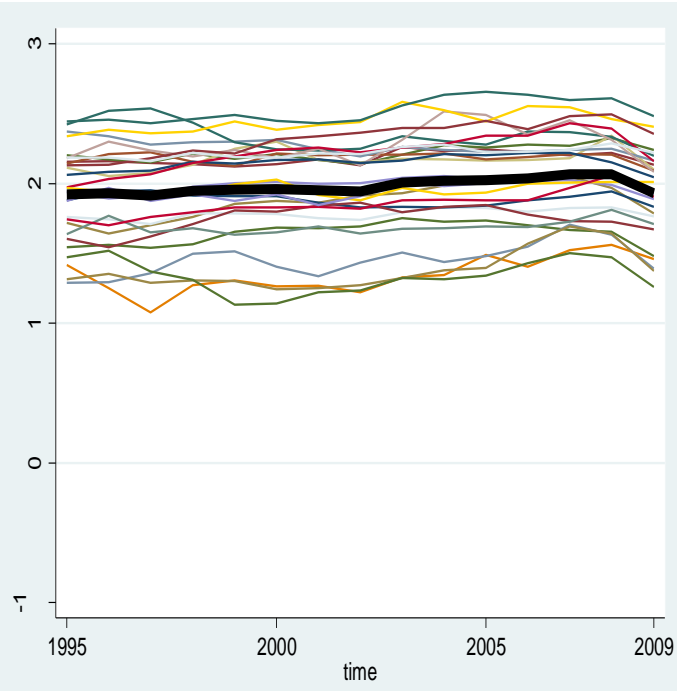

EU-27 countries 
In addition, Tables 2 and 3 show the main descriptive statistics of the variables for the whole sample and only the $27 \mathrm{EU}$ members, respectively. The overall statistics refer to the whole sample, while the within statistics refer to each country and to the variation from each country's average. If a variable does not change over time, its within standard deviation will be zero. The between statistics refer to the standard deviation, and minimum and maximum of the averages for each country. Table 1 shows that the typical standard deviation of the data is higher across countries than across time for all variables, particularly $Q, S$ and $E p$ variables.

Table 2. Descriptive statistics for the whole sample (40 countries) (1995-2009).

\begin{tabular}{|c|c|c|c|c|c|c|}
\hline Variable & & Mean & Std. Dev. & Min. & Max. & Observations \\
\hline \multirow{3}{*}{$E$} & overall & 11.683 & 1.682 & 7.856 & 15.472 & $\mathrm{~N}=600$ \\
\hline & between & & 1.697 & 7.936 & 15.417 & $\mathrm{n}=40$ \\
\hline & within & & 0.117 & 11.291 & 12.142 & $\mathrm{~T}=15$ \\
\hline \multirow{3}{*}{$E p$} & overall & 1.821 & 0.686 & -0.383 & 2.898 & $\mathrm{~N}=600$ \\
\hline & between & & 0.687 & -0.178 & 2.849 & $\mathrm{n}=40$ \\
\hline & within & & 0.098 & 1.451 & 2.240 & $\mathrm{~T}=15$ \\
\hline \multirow{3}{*}{$H D p$} & overall & 1.764 & 1.118 & -1.377 & 3.279 & $\mathrm{~N}=600$ \\
\hline & between & & 1.117 & -1.084 & 3.206 & $\mathrm{n}=40$ \\
\hline & within & & 0.176 & 1.107 & 2.356 & $\mathrm{~T}=15$ \\
\hline \multirow{3}{*}{$T D p$} & overall & 2.313 & 1.137 & -0.904 & 3.996 & $\mathrm{~N}=600$ \\
\hline & between & & 1.137 & -0.591 & 3.880 & $\mathrm{n}=40$ \\
\hline & within & & 0.176 & 1.729 & 2.965 & $\mathrm{~T}=15$ \\
\hline \multirow{3}{*}{$Q$} & overall & 0.197 & 0.093 & 0.037 & 0.470 & $\mathrm{~N}=600$ \\
\hline & between & & 0.092 & 0.054 & 0.452 & $\mathrm{n}=40$ \\
\hline & within & & 0.021 & 0.108 & 0.282 & $\mathrm{~T}=15$ \\
\hline \multirow{3}{*}{$S$} & overall & 0.140 & 0.065 & 0.006 & 0.336 & $\mathrm{~N}=600$ \\
\hline & between & & 0.061 & 0.024 & 0.263 & $\mathrm{n}=40$ \\
\hline & within & & 0.023 & 0.062 & 0.236 & $\mathrm{~T}=15$ \\
\hline
\end{tabular}


Table 3. Descriptive statistics for the 27 member countries of the EU (1995-2009).

\begin{tabular}{|c|c|c|c|c|c|c|}
\hline Variable & & Mean & Std. Dev. & Min. & Max. & Observations \\
\hline \multirow{3}{*}{$E$} & overall & 10.951 & 1.426 & 7.856 & 13.684 & $\mathrm{~N}=405$ \\
\hline & between & & 1.448 & 7.936 & 13.580 & $\mathrm{n}=27$ \\
\hline & within & & 0.096 & 10.599 & 11.258 & $\mathrm{~T}=15$ \\
\hline \multirow{3}{*}{$E p$} & overall & 1.970 & 0.347 & 1.076 & 2.658 & $\mathrm{~N}=405$ \\
\hline & between & & 0.342 & 1.337 & 2.521 & $\mathrm{n}=27$ \\
\hline & within & & 0.086 & 1.709 & 2.290 & $\mathrm{~T}=15$ \\
\hline \multirow{3}{*}{$H D p$} & overall & 1.972 & 0.886 & -0.026 & 3.279 & $\mathrm{~N}=405$ \\
\hline & between & & 0.886 & 0.286 & 3.206 & $\mathrm{n}=27$ \\
\hline & within & & 0.174 & 1.315 & 2.472 & $\mathrm{~T}=15$ \\
\hline \multirow{3}{*}{$T D p$} & overall & 2.536 & 0.922 & 0.278 & 3.996 & $\mathrm{~N}=405$ \\
\hline & between & & 0.922 & 0.684 & 3.880 & $\mathrm{n}=27$ \\
\hline & within & & 0.171 & 1.952 & 3.091 & $\mathrm{~T}=15$ \\
\hline \multirow{3}{*}{$Q$} & overall & 0.236 & 0.084 & 0.100 & 0.470 & $\mathrm{~N}=405$ \\
\hline & between & & 0.082 & 0.119 & 0.452 & $\mathrm{n}=27$ \\
\hline & within & & 0.023 & 0.147 & 0.320 & $\mathrm{~T}=15$ \\
\hline \multirow{3}{*}{$S$} & overall & 0.116 & 0.050 & 0.006 & 0.284 & $\mathrm{~N}=405$ \\
\hline & between & & 0.045 & 0.024 & 0.214 & $\mathrm{n}=27$ \\
\hline & within & & 0.024 & 0.039 & 0.212 & $\mathrm{~T}=15$ \\
\hline
\end{tabular}

\subsection{The relationships between carbon footprints and final demand by countries}

\subsubsection{Single-level model estimates}

Table 4 shows the results of the estimates numbered as 1-8 in the last column in Table 1. Therefore, Table 4 shows the results of estimating [2] for the 40 countries sample when carbon footprints are alternatively expressed in per capita $(E p)$ or absolute terms $(E)$, to reflect total human pressure, as in Luzzati and Orisini (2009). Variable $Y$ in [2] is also alternatively expressed as final demand ( $T D p)$ or final consumption expenditure by households $(H D p)$. 
Additionally, Table 4 shows the results of estimating [2], with and without considering the cubic term of the equation. Table 5 shows the results of the estimates numbered as 21-28, which are similar to previous ones but refer to the EU-27 countries.

The estimates are obtained by using the generalized least squares (GLS) method in the presence of autocorrelation, heteroscedasticity and contemporaneous correlation, according to the results of the Wooldridge (2002) test for autocorrelation, the Wald test for homoscedasticity, proposed in Greene (2000), and the Pesaran (2004) test for contemporaneous correlation. All the 32 estimates included time dummies.

Table 4. Estimate results of equation [2] for world sample.

\begin{tabular}{|c|c|c|c|c|c|c|c|c|}
\hline & \multicolumn{4}{|c|}{$\begin{array}{c}G L S F D \\
\text { Footprint } \\
\text { Carbon Emissions in per capita terms }\end{array}$} & \multicolumn{4}{|c|}{$\begin{array}{c}\text { GLS FD } \\
\text { Footprint } \\
\text { Carbon Emissions in absolute terms }\end{array}$} \\
\hline & \multicolumn{2}{|c|}{ Final demand } & \multicolumn{2}{|c|}{$\begin{array}{l}\text { Final consumption } \\
\text { expenditure by } \\
\text { households }\end{array}$} & \multicolumn{2}{|c|}{ Final demand } & \multicolumn{2}{|c|}{$\begin{array}{l}\text { Final consumption } \\
\text { expenditure by } \\
\text { households }\end{array}$} \\
\hline & Squared & Cubic & Squared & Cubic & Squared & Cubic & Squared & Cubic \\
\hline N. & 1 & 2 & 3 & 4 & 5 & 6 & 7 & 8 \\
\hline$\beta_{1}$ & $\begin{array}{c}1.147 * * * \\
(0.072)\end{array}$ & $\begin{array}{c}1.002^{* * *} \\
(0.060)\end{array}$ & $\begin{array}{c}0.955 * * * \\
(0.096)\end{array}$ & $\begin{array}{c}0.938 * * * \\
(0.079)\end{array}$ & $\begin{array}{c}1.075^{* * *} \\
(0.052)\end{array}$ & $\begin{array}{c}1.089 * * * \\
(0.069)\end{array}$ & $\begin{array}{c}0.943 * * * \\
(0.102)\end{array}$ & $\begin{array}{c}0.993 * * * \\
(0.101)\end{array}$ \\
\hline$\beta_{2}$ & $\begin{array}{c}0.083^{* * *} \\
(0.019)\end{array}$ & $\begin{array}{c}0.096^{* * *} \\
(0.023)\end{array}$ & $\begin{array}{c}0.052 * * \\
(0.024)\end{array}$ & $\begin{array}{c}0.058 \\
(0.044)\end{array}$ & $\begin{array}{c}0.077 * * * \\
(0.012)\end{array}$ & $\begin{array}{c}0.129 * * * \\
(0.039)\end{array}$ & $\begin{array}{c}0.058 * * \\
(0.025)\end{array}$ & $\begin{array}{c}0.139 * * * \\
(0.041)\end{array}$ \\
\hline$\beta_{3}$ & - & $\begin{array}{l}0.020^{* *} \\
(0.009)\end{array}$ & - & $\begin{array}{c}0.002 \\
(0.012)\end{array}$ & - & $\begin{array}{c}0.024 * * \\
(0.009)\end{array}$ & - & $\begin{array}{l}0.024 * \\
(0.013)\end{array}$ \\
\hline
\end{tabular}

Note: Standard errors are shown in parenthesis, *** denotes significant level at $1 \%$, ** at $5 \%$ and $*$ at $10 \%$. All estimates include time dummies. 
Table 5. Estimate results of equation [2] for the EU-27 sample.

\begin{tabular}{|c|c|c|c|c|c|c|c|c|}
\hline & \multicolumn{4}{|c|}{$\begin{array}{c}G L S F D \\
\text { Footprint } \\
\text { Carbon Emissions in per capita terms }\end{array}$} & \multicolumn{4}{|c|}{$\begin{array}{c}G L S F D \\
\text { Footprint } \\
\text { Carbon Emissions in absolute terms }\end{array}$} \\
\hline & \multicolumn{2}{|c|}{ Final demand } & \multicolumn{2}{|c|}{$\begin{array}{l}\text { Final consumption } \\
\text { expenditure by } \\
\text { households }\end{array}$} & \multicolumn{2}{|c|}{ Final demand } & \multicolumn{2}{|c|}{$\begin{array}{l}\text { Final consumption } \\
\text { expenditure by } \\
\text { households }\end{array}$} \\
\hline & Squared & Cubic & Squared & Cubic & Squared & Cubic & Squared & Cubic \\
\hline N. & 21 & 22 & 23 & 24 & 25 & 26 & 27 & 28 \\
\hline$\beta_{1}$ & $\begin{array}{c}1.031 * * * \\
(0.066)\end{array}$ & $\begin{array}{c}1.006^{* * *} \\
(0.071)\end{array}$ & $\begin{array}{c}0.906 * * * \\
(0.079)\end{array}$ & $\begin{array}{c}0.935 * * * \\
(0.092)\end{array}$ & $\begin{array}{c}1.110^{* * *} \\
(0.075)\end{array}$ & $\begin{array}{c}1.096^{* * * *} \\
(0.080)\end{array}$ & $\begin{array}{c}0.935 * * * \\
(0.083)\end{array}$ & $\begin{array}{c}0.864 * * * \\
(0.088)\end{array}$ \\
\hline$\beta_{2}$ & $\begin{array}{c}0.128 * * * \\
(0.016)\end{array}$ & $\begin{array}{c}0.149 * * * \\
(0.018)\end{array}$ & $\begin{array}{c}0.144 * * * \\
(0.027)\end{array}$ & $\begin{array}{c}0.107^{* * *} \\
(0.039)\end{array}$ & $\begin{array}{c}0.156^{* * *} \\
(0.020)\end{array}$ & $\begin{array}{c}0.176^{* * *} \\
(0.022)\end{array}$ & $\begin{array}{c}0.163 * * * \\
(0.023)\end{array}$ & $\begin{array}{c}0.180 * * * \\
(0.033)\end{array}$ \\
\hline$\beta_{3}$ & - & $\begin{array}{c}0.014 \\
(0.013)\end{array}$ & - & $\begin{array}{l}-0.024 \\
(0.022)\end{array}$ & - & $\begin{array}{c}0.013 \\
(0.014)\end{array}$ & - & $\begin{array}{c}0.006 \\
(0.021)\end{array}$ \\
\hline
\end{tabular}

Note: Standard errors are shown in parenthesis, $* * *$ denotes significant level at $1 \%, * *$ at $5 \%$ and $*$ at $10 \%$. All estimates include time dummies.

Table 4 shows that $\beta_{1}$ coefficients are positive and significant in all estimates, therefore in the central point of the sample the elasticity is positive, thus, increases in total final demand per capita or final consumption expenditure by households per capita increases carbon footprints, either in per capita or absolute terms. All these coefficients are close to one, but higher than one when considering final demand. This means that the increase of carbon footprint is more than proportional to the increase of total demand. In this regard, it is worth noting that results in previous studies, which analyzed the households' expenditure elasticity of energy requirements in several countries, show that these elasticities are less than one, with the only exception of Brazil (Cohen et al., 2005; Lenzen et al., 2006). Along this line, Lenzen (1998) finds that Australian households' expenditure elasticity with respect to $\mathrm{CO}_{2}$ requirements was equal to 0.70 , for 1993-1994. Nevertheless, the study by Wier et al. (2001), which evaluates the importance of Danish household consumption pattern on their $\mathrm{CO}_{2}$ requirements, shows that this elasticity is equal to 0.90 , for the year 1995 ; this value being closer to our results. 
Table 4 also shows that $\beta_{2}$ coefficients are positive in all cases, and significant in most of them, with the only exception being the number 4 estimate in per capita terms. Therefore, the EKC hypothesis is not confirmed in any case. Moreover, a positive exponential relationship is confirmed for carbon footprints per capita with respect to final demand, and for carbon footprints in absolute terms with respect to final demand and final consumption expenditure by households, as in all these estimates $\beta_{3}$ is positive and significant. Finally, it is worth noting that no major differences are observed between estimates when the explained variable is given in absolute or per capita terms.

Table 5 shows that the results of the estimates for the EU-27 are similar to those obtained for the world sample, with the exception of the significance of $\beta_{3}$, as none of these coefficients are now significant. Therefore, neither is the EKC hypothesis confirmed for the EU-27 countries in any case.

Table 6 shows the results of the estimates numbered as 9-16 in the last column in Table 1. Therefore, Table 6 shows the results of estimating [4] for the world sample. Table 7 shows the results of the estimates numbered as 29-36, which are similar to previous ones but refer to the EU-27 countries. Equation [4] includes the structure $(S)$ and imports $(Q)$ variables that affect the value of the $\beta_{1}$ coefficient, making equation [2] more flexible. Tables 6 and 7 show the results of these estimates. Nevertheless, these Tables also show the estimates of [4] without including the structure variable, as the value of the coefficient for this variable $\gamma_{1 S}$ is not significant in the complete estimates of [4]. Furthermore, Tables 6 and 7 only show the estimates of [4] when variable $Y$ is final demand (TDp), as the estimates of [4], when variable $Y$ is final consumption expenditure by households, are very similar. 
Table 6. Estimate results of equation [4] for the world sample.

\begin{tabular}{|c|c|c|c|c|c|c|c|c|}
\hline & \multirow{2}{*}{\multicolumn{4}{|c|}{$\begin{array}{c}G L S F D \\
\text { Footprint } \\
\text { Carbon Emissions in per capita terms } \\
\text { Final Demand } \\
\end{array}$}} & \multirow{2}{*}{\multicolumn{4}{|c|}{$\begin{array}{c}G L S F D \\
\text { Footprint } \\
\text { Carbon Emissions in absolute terms } \\
\text { Final Demand } \\
\end{array}$}} \\
\hline & & & & & & & & \\
\hline & \multicolumn{2}{|c|}{ Squared } & \multicolumn{2}{|c|}{ Cubic } & \multicolumn{2}{|c|}{ Squared } & \multicolumn{2}{|c|}{ Cubic } \\
\hline N. & 9 & 10 & 11 & 12 & 13 & 14 & 15 & 16 \\
\hline$\gamma_{1}$ & $\begin{array}{c}1.002 * * * \\
(0.046)\end{array}$ & $\begin{array}{c}0.997 * * * \\
(0.045)\end{array}$ & $\begin{array}{c}0.993 * * * \\
(0.047)\end{array}$ & $\begin{array}{c}0.988 * * * \\
(0.047)\end{array}$ & $\begin{array}{c}0.951 * * * \\
(0.040)\end{array}$ & $\begin{array}{c}1.043 * * * \\
(0.050)\end{array}$ & $\begin{array}{c}0.984 * * * \\
(0.050)\end{array}$ & $\begin{array}{c}0.986 * * * \\
(0.051)\end{array}$ \\
\hline$\beta_{2}$ & $\begin{array}{c}0.044 * * * \\
(0.015)\end{array}$ & $\begin{array}{c}0.042 * * * \\
(0.014)\end{array}$ & $\begin{array}{c}0.060 * * \\
(0.027)\end{array}$ & $\begin{array}{c}0.061 * * \\
(0.027)\end{array}$ & $\begin{array}{c}0.070 * * * \\
(0.020)\end{array}$ & $\begin{array}{c}0.062 * * * \\
(0.014)\end{array}$ & $\begin{array}{c}0.078 * * * \\
(0.020)\end{array}$ & $\begin{array}{c}0.081 * * * \\
(0.020)\end{array}$ \\
\hline$\beta_{3}$ & - & - & $\begin{array}{c}0.008 \\
(0.010)\end{array}$ & $\begin{array}{c}0.009 \\
(0.009)\end{array}$ & - & - & $\begin{array}{c}0.009 \\
(0.010)\end{array}$ & $\begin{array}{c}0.010 \\
(0.010)\end{array}$ \\
\hline$\gamma_{1 Q}$ & $\begin{array}{c}0.627 * * * \\
(0.065)\end{array}$ & $\begin{array}{c}0.613 * * * \\
(0.046)\end{array}$ & $\begin{array}{c}0.574 * * * \\
(0.071)\end{array}$ & $\begin{array}{c}0.568 * * * \\
(0.051)\end{array}$ & $\begin{array}{c}0.578 * * * \\
(0.118)\end{array}$ & $\begin{array}{c}0.633 * * * \\
(0.048)\end{array}$ & $\begin{array}{c}0.539 * * * \\
(0.081)\end{array}$ & $\begin{array}{c}0.521 * * * \\
(0.074)\end{array}$ \\
\hline$\gamma_{1 S}$ & $\begin{array}{c}0.045 \\
(0.106)\end{array}$ & - & $\begin{array}{c}0.024 \\
(0.118)\end{array}$ & - & $\begin{array}{c}0.211 \\
(0.131)\end{array}$ & - & $\begin{array}{c}0.034 \\
(0.093)\end{array}$ & - \\
\hline
\end{tabular}

Table 7. Estimate results of equation [4] for the EU-27 sample.

\begin{tabular}{|c|c|c|c|c|c|c|c|c|}
\hline & \multirow{2}{*}{\multicolumn{4}{|c|}{$\begin{array}{c}G L S F D \\
\text { Footprint } \\
\text { Carbon Emissions in per capita terms } \\
\text { Final Demand }\end{array}$}} & \multirow{2}{*}{\multicolumn{4}{|c|}{$\begin{array}{c}G L S F D \\
\text { Footprint } \\
\text { Carbon Emissions in absolute terms } \\
\text { Final Demand }\end{array}$}} \\
\hline & & & & & & & & \\
\hline & \multicolumn{2}{|c|}{ Squared } & \multicolumn{2}{|c|}{ Cubic } & \multicolumn{2}{|c|}{ Squared } & \multicolumn{2}{|c|}{ Cubic } \\
\hline N. & 29 & 30 & 31 & 32 & 33 & 34 & 35 & 36 \\
\hline$\gamma_{1}$ & $\begin{array}{c}0.971 * * * \\
(0.075)\end{array}$ & $\begin{array}{c}0.963 * * * \\
(0.072)\end{array}$ & $\begin{array}{c}0.960 * * * \\
(0.075)\end{array}$ & $\begin{array}{c}0.959 * * * \\
(0.073)\end{array}$ & $\begin{array}{c}1.095 * * * \\
(0.077)\end{array}$ & $\begin{array}{c}1.102 * * * \\
(0.076)\end{array}$ & $\begin{array}{c}1.035 * * * \\
(0.082)\end{array}$ & $\begin{array}{c}1.047 * * * \\
(0.081)\end{array}$ \\
\hline$\beta_{2}$ & $\begin{array}{c}0.092 * * * \\
(0.027)\end{array}$ & $\begin{array}{c}0.088 * * * \\
(0.026)\end{array}$ & $\begin{array}{c}0.117 * * * \\
(0.026)\end{array}$ & $\begin{array}{c}0.113 * * * \\
(0.025)\end{array}$ & $\begin{array}{c}0.129 * * * \\
(0.023)\end{array}$ & $\begin{array}{c}0.129 * * * \\
(0.023)\end{array}$ & $\begin{array}{c}0.166^{* * * *} \\
(0.025)\end{array}$ & $\begin{array}{c}0.166 * * * \\
(0.025)\end{array}$ \\
\hline$\beta_{3}$ & $\begin{array}{l}- \\
-\end{array}$ & - & $\begin{array}{c}0.009 \\
(0.012)\end{array}$ & $\begin{array}{c}0.008 \\
(0.012)\end{array}$ & - & - & $\begin{array}{c}0.030 * * \\
(0.014)\end{array}$ & $\begin{array}{c}0.028 * * \\
(0.014)\end{array}$ \\
\hline$\gamma_{1 Q}$ & $\begin{array}{c}0.161 \\
(0.118)\end{array}$ & $\begin{array}{c}0.147 \\
(0.113)\end{array}$ & $\begin{array}{c}0.278 * * * \\
(0.093)\end{array}$ & $\begin{array}{c}0.262 * * * \\
(0.086)\end{array}$ & $\begin{array}{c}0.288 * * \\
(0.130)\end{array}$ & $\begin{array}{c}0.245 * * \\
(0.117)\end{array}$ & $\begin{array}{c}0.283 * * \\
(0.120)\end{array}$ & $\begin{array}{c}0.248 * * \\
(0.107)\end{array}$ \\
\hline$\gamma_{1 S}$ & $\begin{array}{c}0.076 \\
(0.164)\end{array}$ & - & $\begin{array}{c}0.019 \\
(0.147)\end{array}$ & $\begin{array}{lll}- & -1 \\
\end{array}$ & $\begin{array}{c}0.119 \\
(0.214)\end{array}$ & $\begin{array}{lll}- & - \\
\end{array}$ & $\begin{array}{c}0.062 \\
(0.202)\end{array}$ & $\begin{array}{lll}- & - \\
\end{array}$ \\
\hline
\end{tabular}

Note: Standard errors are shown in parenthesis, $* * *$ denotes significant level at $1 \%$, ** at $5 \%$ and $*$ at $10 \%$. All estimates include time dummies.

Table 6 does not show the value of $\beta_{l}$ coefficients directly, as they depend on the value of $\gamma_{1}$,

$\gamma_{1 S}$ and $\gamma_{1 Q}$ as equation [3] shows. The $\gamma_{1}$ coefficients are all positive and significant with 
values close to one. Thus, increases in total final demand per capita increase carbon footprints, either in per capita or absolute terms. Nevertheless, as the effect also depends on the $\gamma_{1 Q}$ and $\gamma_{I S}$ coefficients, and the values of the variables $Q$ and $S$, their values have to be taken into account. The $\gamma_{1 Q}$ coefficients are positive and significant in all cases. The $\gamma_{1 S}$ coefficients are also positive but they are not significant. The values of $Q$ and $S$ variables are also positive, as they represent percentage values. Therefore the value of the $\beta_{l}$ coefficients are positive in all cases, and are also going to be higher than one, as this value is the sum of $\gamma_{1}$ coefficients and the products of $\gamma_{1 Q} * Q$ and $\gamma_{1 S} * S$. Nevertheless, as $\gamma_{1 S}$ coefficients are not significant, Table 6 also shows the estimates without including the variable $S$. In these cases, the exclusion of this variable does not seem to notably affect the other coefficient values. Therefore the value of the $\beta_{1}$ coefficients are now only the sum of $\gamma_{1}$ coefficients and the products of $\gamma_{1 Q} * Q$. Even so, the $\beta_{1}$ coefficient values are going to be positive and higher than one, showing that increases in final demand per capita provoke more than proportional increases of carbon footprints. Once again, the EKC hypothesis is not confirmed.

It is also worth noting that now the $\beta_{1}$ coefficient values are not constant, but vary with the value of the $Q$ variable, which shows the import profile of each country. Thus, the higher the percentage of imports of a country, the higher is the coefficient $\beta_{1}$ value, generating more footprints per unit of final demand. These results may not only be related to the displacement of polluting industries to countries where environmental standards are relatively low, as stated in Lau et al. (2014), but also to the increase of transport activities because of the higher international trade.

Table 7 shows that the results of the estimates for the EU-27 are similar to those obtained for the world sample, with the exception of the significance of $\gamma_{1 Q}$ for the estimates numbered 29 and 30, referring to squared estimates and final demand per capita. Similarly, the values of 
these coefficients for all estimates are considerably lower with respect to those of the world sample. In this sense, it may be noted that a high percentage of imports of each of the EU-27 countries come from another EU-27 country. Therefore, the carbon footprints associated with transport and trade are going to be smaller, as these activities are mostly being developed in a limited geographical sphere. Additionally, it is worth noting that the pollution intensities and technologies are relatively similar within the EU-27, and these countries have relatively high environmental standards, which may also be associated with smaller carbon footprints.

\subsubsection{Multi-level model estimates}

Table 8 shows the results of the estimates numbered as 17-20 in the last column in Table 1. Therefore, Table 8 shows the results of estimating [5] for the world sample by using a multilevel mixed model. Table 9 shows the results of the estimates numbered as 37-40, which are similar to previous ones but refer to the EU-27 countries. Equation [5] also includes a random term in the $\beta_{1}$ coefficient allowing it to vary randomly across countries, as shown in [8] with the aim of defining a more flexible model. Additionally, equation [5] also includes a random term in the $\beta_{2}$ coefficient to make the equation even more flexible, as defined in [6]. The estimates are obtained using the maximum likelihood (ML) method, allowing heteroskedasticity and correlations to be modeled within lowest-level groups. The random effects are not directly estimated, but can be obtained according to their estimated variances and covariances.

The estimates shown in Tables 8 and 9 do not include the structure variable, as before, and the cubic term of $Y$, with the aim of simplifying estimates. These variables are not significant in any case and AIC and BIC tests indicate that their inclusion provides no further quality to the model. Additionally, Tables 8 and 9 also include the estimates of the standard deviations $\left(s d\left(\beta_{1}\right)\right.$ and $\left.s d\left(\beta_{s}\right)\right)$ of the $\beta_{1}$ and $\beta_{2}$ coefficients. 
Table 8. Estimate results of equation [5] for the world sample.

\begin{tabular}{|c|c|c|c|c|}
\hline & \multirow{2}{*}{\multicolumn{2}{|c|}{$\begin{array}{c}\text { Multilevel Model } \\
\text { Footprint } \\
\text { Carbon Emissions in per capita terms } \\
\text { Final Demand }\end{array}$}} & \multirow{2}{*}{\multicolumn{2}{|c|}{$\begin{array}{c}\text { Multilevel Model } \\
\text { Footprint } \\
\text { Carbon Emissions in absolute terms } \\
\text { Final Demand }\end{array}$}} \\
\hline & & & & \\
\hline & \multicolumn{2}{|c|}{ Squared } & \multicolumn{2}{|c|}{ Squared } \\
\hline N. & 17 & 18 & 19 & 20 \\
\hline$\gamma_{1}$ & $\begin{array}{c}1.011 * * * \\
(0.075)\end{array}$ & $\begin{array}{c}1.018 * * * \\
(0.075)\end{array}$ & $\begin{array}{c}1.016 * * * \\
(0.082)\end{array}$ & $\begin{array}{c}1.033 * * * \\
(0.080)\end{array}$ \\
\hline$\gamma_{2}$ & $\begin{array}{l}0.043 * \\
(0.025)\end{array}$ & $\begin{array}{l}0.048^{*} \\
(0.027)\end{array}$ & $\begin{array}{l}0.050 * \\
(0.028)\end{array}$ & $\begin{array}{l}0.064 * \\
(0.033)\end{array}$ \\
\hline$\gamma_{1 Q}$ & $\begin{array}{c}0.629 * * * \\
(0.115)\end{array}$ & $\begin{array}{c}0.634 * * * \\
(0.115)\end{array}$ & $\begin{array}{c}0.607 * * * \\
(0.120)\end{array}$ & $\begin{array}{c}0.614 * * * \\
(0.120)\end{array}$ \\
\hline$s d\left(\beta_{1}\right)$ & $\begin{array}{c}0.206 * * * \\
(0.053)\end{array}$ & $\begin{array}{c}0.194 * * * \\
(0.059)\end{array}$ & $\begin{array}{c}0.253 * * * \\
(0.058)\end{array}$ & $\begin{array}{c}0.205^{* * *} \\
(0.068)\end{array}$ \\
\hline$s d\left(\beta_{2}\right)$ & - & $\begin{array}{c}0.038 \\
(0.049)\end{array}$ & - & $\begin{array}{l}0.080 * \\
(0.041)\end{array}$ \\
\hline
\end{tabular}

Note: Standard errors are shown in parenthesis, $* * *$ denotes significant level at $1 \%$, $* *$ at $5 \%$ and $*$ at $10 \%$. All estimates include time dummies.

Table 9. Estimate results of equation [5] for the EU-27 sample.

\begin{tabular}{|c|c|c|c|c|c|}
\hline & \multicolumn{2}{|c|}{$\begin{array}{c}\text { Multilevel Model } \\
\text { Footprint } \\
\text { Carbon Emissions in per capita terms }\end{array}$} & \multicolumn{3}{|c|}{$\begin{array}{c}\text { Multilevel Model } \\
\text { Footprint } \\
\text { Carbon Emissions in absolute terms }\end{array}$} \\
\hline & \multicolumn{2}{|c|}{ Final Demand } & \multicolumn{3}{|c|}{ Final Demand } \\
\hline & \multicolumn{2}{|c|}{ Squared } & \multicolumn{3}{|c|}{ Squared } \\
\hline N. & 37 & 38 & 39 & & \\
\hline$\gamma_{1}$ & $\begin{array}{c}0.953 * * * \\
(0.106)\end{array}$ & $\begin{array}{c}0.959 * * * \\
(0.104)\end{array}$ & $\begin{array}{c}0.976 * * * \\
(0.110)\end{array}$ & & \\
\hline$\gamma_{2}$ & $\begin{array}{c}0.073 * * \\
(0.036)\end{array}$ & $\begin{array}{c}0.081^{* *} \\
(0.037)\end{array}$ & $\begin{array}{c}0.101 * * * \\
(0.037)\end{array}$ & & \\
\hline$\gamma_{1 Q}$ & $\begin{array}{c}0.364 * * \\
(0.149)\end{array}$ & $\begin{array}{c}0.368^{* *} \\
(0.149)\end{array}$ & $\begin{array}{c}0.325^{* *} \\
(0.153)\end{array}$ & & \\
\hline$s d\left(\beta_{1}\right)$ & $\begin{array}{l}0.113^{*} \\
(0.062)\end{array}$ & $\begin{array}{c}0.078 \\
(0.122)\end{array}$ & $\begin{array}{c}0.127 * * \\
(0.063)\end{array}$ & 0.088 & $(0.118)$ \\
\hline$s d\left(\beta_{2}\right)$ & - & $\begin{array}{c}0.043 \\
(0.051)\end{array}$ & - & 0.049 & $(0.047)$ \\
\hline
\end{tabular}

Note: Standard errors are shown in parenthesis, $* * *$ denotes significant level at $1 \%$, $* *$ at $5 \%$ and $*$ at $10 \%$. All estimates include time dummies. 
Table 8 shows that the values of the $\beta_{1}$ coefficients depend on the values of $\gamma_{1}$ and $\gamma_{1 Q}$, and that they also vary randomly across countries, as the standard deviation of $\beta_{l}$ is significantly different to zero. Nevertheless, the standard deviation of $\beta_{2}$ is not significantly different to zero for the carbon footprints per capita estimate. In order to test if it is better or not to include $\beta_{2}$ random variation in the model, a likelihood-ratio test (LR test) was performed. This test compares the log-likelihood of both models (with and without $\beta_{2}$ random variation), testing the null hypothesis that there is no significant difference between them. As the LR test value is equal to $\operatorname{chi}^{2}(1)=0.21$, when comparing estimates numbered 17 and 18 , the null hypothesis may not be rejected. Therefore, the $\beta_{2}$ random variation may be omitted. Similarly, the LR test comparing estimates numbered 19 and 20 displays a similar conclusion. Additionally, the LR test was used to compare this multilevel model with a single one in which random effects are not included. In this case, the null hypothesis may be rejected, and therefore it can been inferred that the multilevel model is preferred to the single one.

Table 8 shows that $\gamma_{1}$ coefficients are all positive and significant with values near to 1 , and $\gamma_{1 Q}$ coefficients are also positive and significant in all cases. In order to calculate the value of $\beta_{1}$ coefficients, it is necessary to previously obtain the random effects $\left(\mu_{1 i}\right)$ and the $b_{1}$ value corresponding to each country $i$ according to [6]. The $b_{1}$ values obtained from the estimate numbered 17, considering carbon footprints per capita, are shown in Table 10 . The $b_{1}$ values obtained from the estimate numbered 19 are not shown in Table 10 as they report very similar results. As observed, these values vary between countries depending on random effects. Estonia has the lowest value, equal to 0.623 , and Korea the highest with 1.300 . From these values, $\beta_{1}$ coefficients are obtained for each country, taking into account that these coefficients depend on variable $Q$, also for each year. Table 10 shows the average $\beta_{l}$ values across time, for each country. Estonia and Korea still have the lowest and highest values, 0.694 and 1.269 respectively. It is worth noting that all average $\beta_{1}$ values are positive, 
although these values are not close to one for some countries (Estonia, Finland, Russia and the Slovak Republic) and much higher than one for some others (Brazil, Cyprus, Indonesia, Korea and Spain).

Table 10. Average $\beta_{1}$ coefficient and elasticity of carbon footprints per capita with respect to total demand per capita by countries (world sample).

\begin{tabular}{|c|c|c|c|c|c|c|c|}
\hline \multicolumn{8}{|c|}{ Whole sample } \\
\hline Country & $b_{1 i}$ & $\bar{\beta}_{1 i}$ & $\overline{e l a s}_{i}$ & Country & $b_{1 i}$ & $\bar{\beta}_{1 i}$ & $\overline{e l a s}_{i}$ \\
\hline AUSTRALIA & 1.037 & 0.977 & 1.056 & JAPAN & 0.968 & 0.878 & 1.001 \\
\hline AUSTRIA & 1.007 & 1.024 & 1.122 & KOREA & 1.300 & 1.269 & 1.296 \\
\hline BELGIUM & 1.042 & 1.099 & 1.188 & LATVIA & 0.896 & 0.926 & 0.830 \\
\hline BRAZIL & 1.276 & 1.191 & 1.122 & LITHUANIA & 0.934 & 0.997 & 0.895 \\
\hline BULGARIA & 1.060 & 1.098 & 0.956 & LUXEMBOURG & 0.852 & 1.013 & 1.149 \\
\hline CANADA & 1.043 & 1.033 & 1.101 & MALTA & 0.904 & 1.039 & 1.059 \\
\hline CHINA & 1.040 & 0.966 & 0.767 & MEXICO & 1.120 & 1.090 & 1.016 \\
\hline CYPRUS & 1.212 & 1.264 & 1.295 & NETHERLANDS & 0.953 & 0.978 & 1.066 \\
\hline CZECH REPUBLIC & 0.945 & 0.973 & 0.939 & POLAND & 0.898 & 0.878 & 0.813 \\
\hline DENMARK & 0.942 & 0.947 & 1.053 & PORTUGAL & 1.079 & 1.075 & 1.098 \\
\hline ESTONIA & 0.623 & 0.694 & 0.631 & ROMANIA & 1.001 & 0.995 & 0.870 \\
\hline FINLAND & 0.842 & 0.822 & 0.906 & RUSSIA & 0.858 & 0.801 & 0.687 \\
\hline FRANCE & 1.026 & 0.983 & 1.070 & SLOVAK REPUBLIC & 0.839 & 0.899 & 0.839 \\
\hline GERMANY & 1.029 & 1.004 & 1.099 & SLOVENIA & 0.982 & 1.027 & 1.047 \\
\hline GREECE & 1.042 & 1.031 & 1.080 & SPAIN & 1.189 & 1.153 & 1.204 \\
\hline HUNGARY & 1.047 & 1.106 & 1.056 & SWEDEN & 1.097 & 1.091 & 1.181 \\
\hline INDIA & 0.955 & 0.911 & 0.725 & TURKEY & 1.078 & 1.029 & 0.964 \\
\hline INDONESIA & 1.269 & 1.198 & 0.945 & TAIWAN & 0.905 & 0.925 & 0.960 \\
\hline IRELAND & 1.042 & 1.115 & 1.176 & UNITED KINGDOM & 1.032 & 0.995 & 1.067 \\
\hline ITALY & 1.075 & 1.026 & 1.087 & UNITED STATES & 1.019 & 0.940 & 1.045 \\
\hline
\end{tabular}

Table 8 also shows that $\gamma_{2}$ coefficients are positive and significant. These coefficients are equal to $\beta_{2}$ values in estimates numbered 17 and 19 , as random effects were not significant. Therefore, the EKC hypothesis may not be supported.

Table 9 shows that the results of the estimates for the EU-27 are similar to those obtained for the world sample. In addition, the LR test results display similar conclusions, and therefore 
the multilevel model is preferred to the single one, and the $\beta_{2}$ random variation may be omitted. Table 11 shows $b_{1}$ values and average $\beta_{1}$ values across time, for each European country, obtained from the estimate numbered 37, considering carbon footprints per capita. Estonia has the lowest average $\beta_{l}$ value and Cyprus the highest. Additionally, it is worth noting that the values of $\gamma_{1 Q}$ coefficients are again considerably lower with respect to those of the world sample.

Table 11. Average $\beta_{l}$ coefficient and elasticity of carbon footprints per capita with respect to total demand per capita by countries (EU-27 sample).

\begin{tabular}{|c|c|c|c|c|c|c|c|}
\hline \multicolumn{7}{|c|}{ EU-27 sample } \\
\hline Country & $\boldsymbol{b}_{1 i}$ & $\bar{\beta}_{1 i}$ & $\overline{\text { elas }}_{i}$ & Country & $\boldsymbol{b}_{1 i}$ & $\bar{\beta}_{1 i}$ & $\overline{\text { elas }}_{i}$ \\
\hline AUSTRIA & 0.951 & 0.947 & 1.079 & LATVIA & 0.947 & 0.951 & 0.756 \\
\hline BELGIUM & 0.966 & 0.984 & 1.101 & LITHUANIA & 0.972 & 0.994 & 0.791 \\
\hline BULGARIA & 1.021 & 1.029 & 0.759 & LUXEMBOURG & 0.908 & 0.987 & 1.183 \\
\hline CYPRUS & 1.027 & 1.043 & 1.062 & MALTA & 0.924 & 0.988 & 0.989 \\
\hline CZECH REPUBLIC & 0.942 & 0.945 & 0.855 & NETHERLANDS & 0.935 & 0.935 & 1.050 \\
\hline DENMARK & 0.936 & 0.926 & 1.069 & POLAND & 0.928 & 0.902 & 0.761 \\
\hline ESTONIA & 0.776 & 0.802 & 0.665 & PORTUGAL & 0.979 & 0.963 & 0.970 \\
\hline FINLAND & 0.897 & 0.872 & 0.981 & ROMANIA & 0.991 & 0.974 & 0.731 \\
\hline FRANCE & 0.956 & 0.917 & 1.030 & SLOVAK REPUBLIC & 0.913 & 0.934 & 0.800 \\
\hline GERMANY & 0.957 & 0.928 & 1.055 & SLOVENIA & 0.953 & 0.965 & 0.966 \\
\hline GREECE & 0.973 & 0.952 & 1.001 & SPAIN & 1.017 & 0.982 & 1.036 \\
\hline HUNGARY & 0.976 & 0.996 & 0.879 & SWEDEN & 0.979 & 0.961 & 1.079 \\
\hline IRELAND & 0.979 & 1.007 & 1.077 & UNITED KINGDOM & 0.959 & 0.923 & 1.012 \\
\hline ITALY & 0.972 & 0.929 & 0.999 & & & & \\
\hline
\end{tabular}

\subsubsection{Carbon Footprints per capita elasticities with respect to final demand}

The carbon footprints per capita elasticities with respect to per capita final demand were calculated for each country and year, according to [7]. The results obtained from estimates numbered 17 and 37 were used. Therefore, the final equation used is the following:

$e l a_{i t}=\gamma_{i t}+\mu_{1 i}+\gamma_{1 Q} \bar{Q}_{i t}+2 \gamma_{2} \bar{Y}_{i t}$ 
Figure 3 shows these elasticities for the world and the EU-27 samples. The elasticities vary with time and between countries. All the elasticities calculated are positive and are spread around the thick-dash black line, which represents the average of the whole sample values for each year. It is worth noting that these average values in both graphs are close to one for the whole period, these values being clearly over one for the world sample. Additionally, both samples show a slight growth trend, except for the last two years, in which the elasticities fall sharply, which may be related to the financial crisis. Nevertheless, the annual elasticity values for each country lie around the average, giving an inter-country difference of up to 0.3 points above, and 0.4 below, for the whole sample, and 0.2 and 0.4 for the EU-27 sample. Therefore, important differences between countries are observed, although a growth trend is observed for most of them. Countries with elasticity values below the average trend show a higher growth trend. This is especially marked for the EU-27 countries. In addition, it may be highlighted that there is a wide group of countries in which elasticity values are higher than one, so their carbon footprints increase proportionately higher than increases in final demand. The average elasticity values across time for each country are shown in Tables 10 and 11.

Figure 3: Carbon footprints per capita elasticities with respect to final demand for each country.

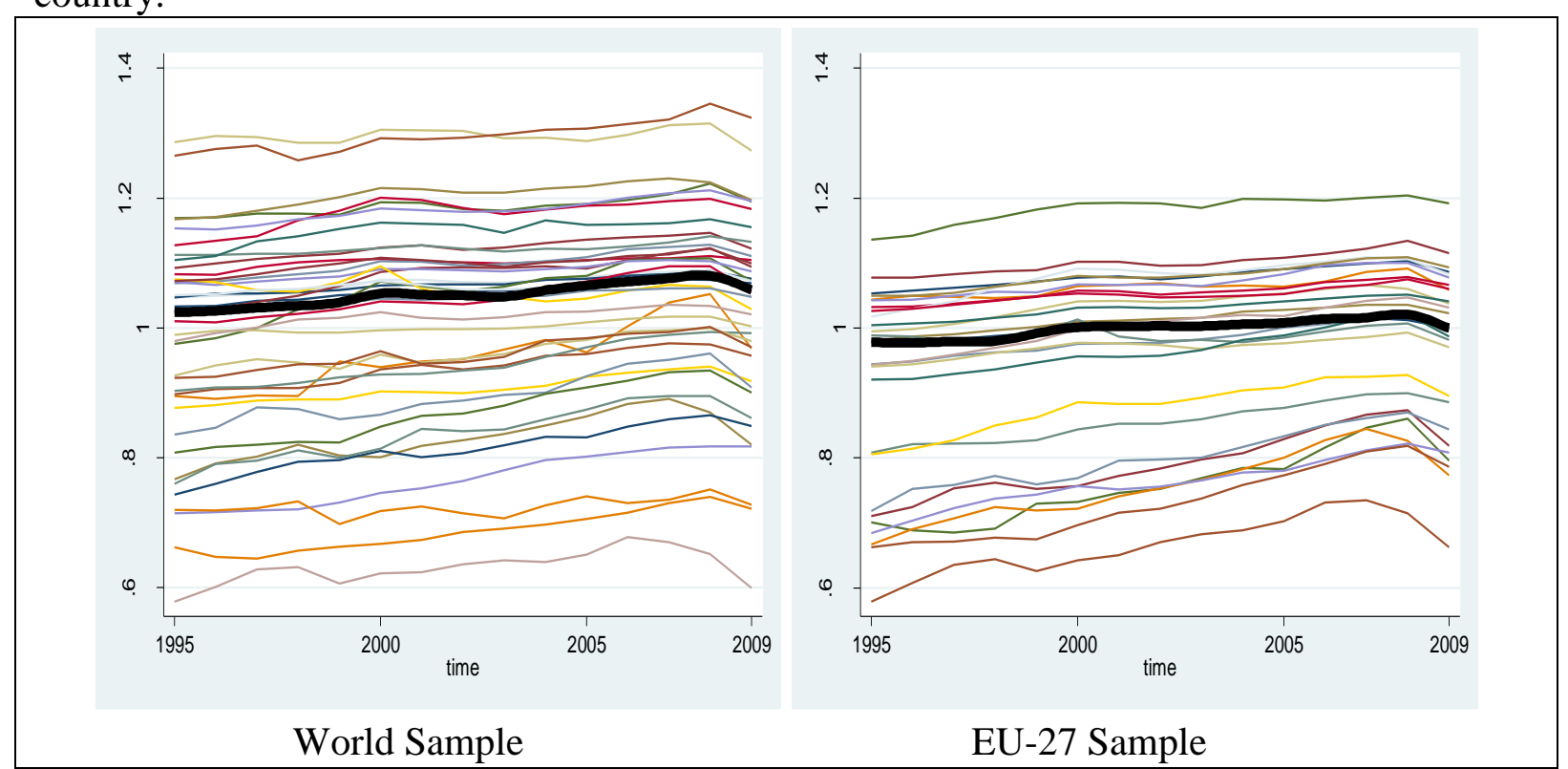


Figure 4 displays the carbon footprint elasticity values with respect to final demand per capita, and for each level of final demand in per capita terms for the world and the EU-27 samples. The elasticity values show that the EKC is not supported in either case, as elasticities increase with final demand per capita. Additionally, this Figure also shows notable differences between countries. The EU-27 sample graph in Figure 4 clearly shows two different groups of countries. Those with lower final demand values register elasticities below one, while those with higher final demand values generally register elasticities above one, the latter being the EU-15 countries. Nevertheless, the elasticity trend of the first group is similar to the second, which may infer high elasticity values for the first group of countries when they reach final demand levels similar to the second group of countries.

Figure 4. Carbon footprints per capita elasticities per final demand per capita level.

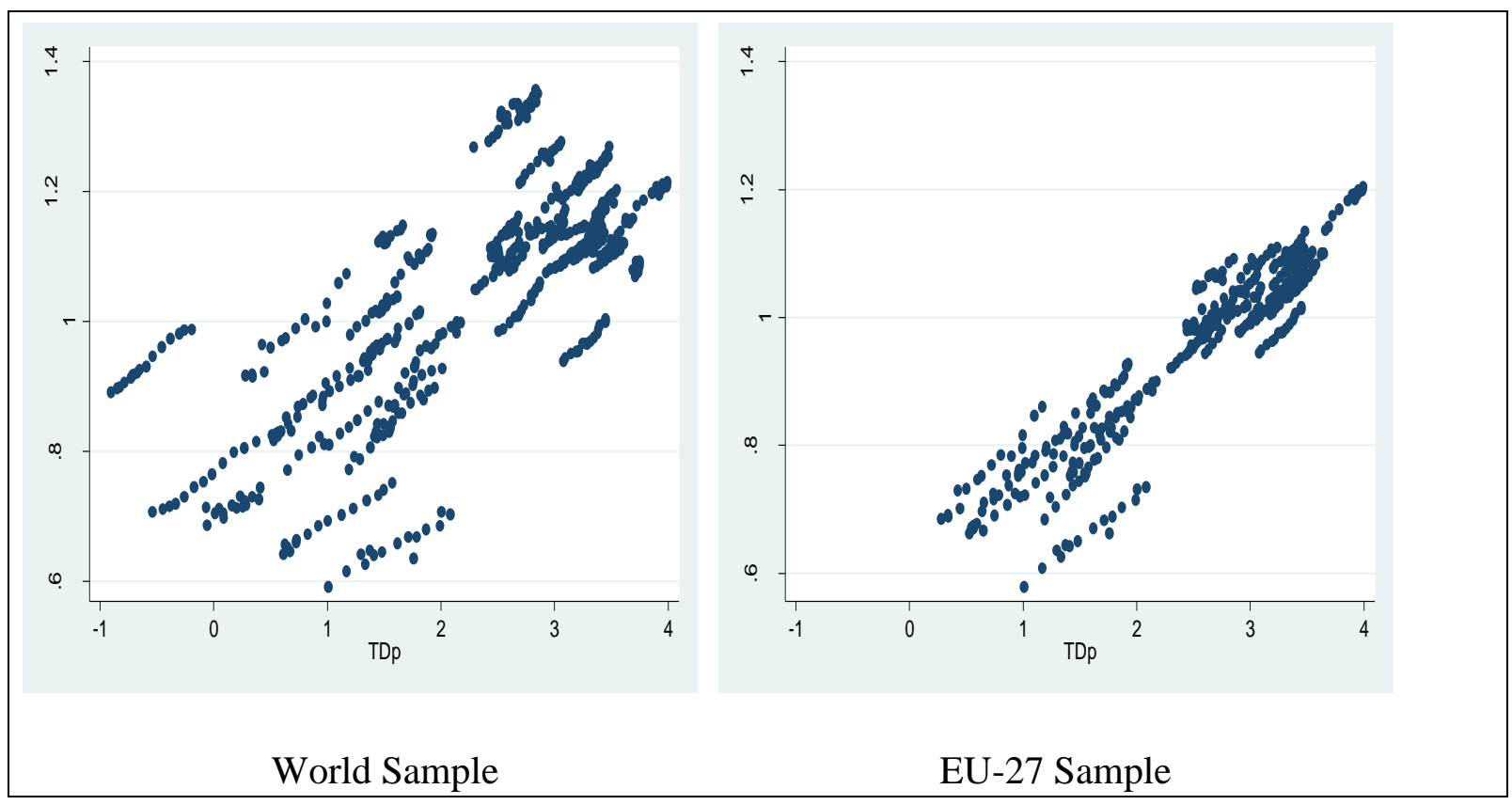

\section{DISCUSSION AND POLICY IMPLICATIONS}

Recently, several papers have focused on carbon footprints instead of $\mathrm{CO}_{2}$ emissions, and on the relationships between these footprints and trade, analyzing how global trade has displaced 
the generation of emissions from developed to developing countries through industrial dislocation. Following these studies, this paper has focused on the relationship between the carbon footprints of countries and their final demand.

The previously obtained results show that the elasticity values of carbon footprints with respect to final demand, both in per capita terms, are generally slightly higher than one, with the relationship between carbon footprints and final demand increases being slightly more than proportional. Therefore, the final demand increases may be considered an important factor in explaining emissions growth. Arto and Dietzenbacher (2014) find that the change in consumption per capita was the main driver for the growth in global GHG emissions. Likewise, Malik et al. (2016) demonstrate that per-capita consumption and population growth are outpacing any improvements in carbon efficiency and driving up emissions worldwide. Thus, energy and environmental policies have not been effective enough to decrease the relationships between emissions and demand, or at least to decrease increments. This is perhaps because the countries have no control over, or cannot lobby for, reductions in the emissions that are generated in the rest of the world, when their citizens, administrations or companies are demanding goods and services. $\mathrm{Xu}$ and Dietzenbacher (2014) state that producers and consumers in developed countries have shifted towards importing a larger share of products from emerging countries, increasing the emissions embodied in imports for developed countries and the emissions embodied in exports for emerging countries. Therefore, a global energy and environmental policy is necessary, or, as recommended in $\mathrm{Xu}$ and Dietzenbacher (2014), it is at least necessary to monitor emissions embodied in trade, and take the effects of trade on emissions into consideration when these policies are designed.

Additionally, the results also show that these elasticities vary between countries and are higher as final demand per capita is larger, becoming higher than one in the richest countries. Therefore, the differences in the levels of final demand per capita between countries are producing a difference in carbon footprint generation among them. It may be questioned why 
countries with higher final demand per capita generate carbon footprint levels at higher proportions than those with a lower one. Attempting to answer this question opens new research lines.

One possible research line may be to analyze if the consumption pattern of countries changes, including more polluted goods, as they become richer, which could be explored by using the WIOD database, as the consumption patterns of each country's consumers are somehow represented in the country input-output tables. On the one hand, some previous studies indicate differences in the kind of goods and services mainly consumed, by diverse income level countries, which have different environmental pressures (UNEP, 2010). In this respect, Lenzen et al. (2006), find differences in average energy requirements due to some countries characteristics such as population density, technology or consumer lifestyles. Additionally, Hertwich and Peters (2009) show that the relationships between the carbon footprints and expenditure are different for several consumption categories.

On the other hand, the consumption of goods with high levels of environmental pressure in richer countries may be associated with industrial dislocation, as the consumer in the richer country does not perceive the pollution he is generating in developing countries with his consumption. The pollution is not directly suffered by the consumer. In this respect, countries could establish some kind of label that informs about the emissions that have been involved in the production of the goods or services that are being imported by the rest of the world.

Another possible research line may study whether the richer countries are those involved in a more global trade, and whether this greater trade is generating greater emission levels. The results obtained in this study may be leaning to this idea, as the import variable $(Q)$ is positively affecting the extent to which final demand provokes carbon footprints. Nevertheless, it may be taken into account that this effect is limited, as the gross part of footprints is generated in the home countries. The results of this study may be reflecting that 
scenario, as although there are differences between $b_{1}$ values and average $\beta_{1}$ values across time, these differences are not very large. Arto and Dietzenbacher (2014) find that the effects of the changes in the structure of international trade were also positive in explaining the global GHG emissions growth between 1995 and 2008, although they were relatively small. Similarly, the findings in Peters et al. (2011) also seem to be pointing in the same direction.

Consequently, the question of whether trade is causing more emissions or not, is not as important as which kind of goods and services are been demanded and traded. This could also be analyzed by using the WIOD database. Additionally, it is important to analyze what energy intensity is associated with their production, also whether this energy is dirty or clean. In this regard, the results also show that smaller emissions are generated when demanded goods and services are mostly produced in those countries with higher environmental standards. Accordingly, the global commitment to reduce emissions requires the worldwide harmonization of high environmental standards. Thus, trade may not be increasing global emission levels, but avoiding reducing them, limiting the effectiveness of applied national and regional energy and environmental policies. Therefore, in addition to continuing to promote national energy and environmental policies to control emissions generated within countries through their own production, it is recommended to promote other policies oriented to discouraging the demand for dirty energy intensive goods and services.

\section{CONCLUSIONS}

The problems of global warming and environmental pollution have led many countries to begin to implement measures to reduce the use of fossil fuels, reducing their emissions and even fulfilling their Kyoto Protocol $\mathrm{CO}_{2}$ reduction commitments. However, these emissions reductions may have been achieved because of the displacement of emissions intensive production to developing countries. Therefore, exploring the relationship between GDP, 
energy consumption and carbon emissions by studying the EKC hypothesis may become meaningless from a global point of view, as it does not provide knowledge on what is happening behind country borders.

In this study, the relationships between the emissions that have been caused by countries from a demand point of view, and the demand for goods and services in these countries, have been analyzed by a two-step process. Carbon footprints were calculated for the period 1995-2009 and for forty countries worldwide. Then, the relationships between these carbon footprints and total final demand were analyzed for these 40 countries and the EU-27 sample countries, by using panel data techniques and a multilevel mixed-effects model. Additionally, the elasticity of carbon footprints with respect to total demand was calculated for each year and country, examining whether there is a different behavior between countries.

The obtained results show that the EKC is not supported when considering carbon footprints with respect to final demand instead of $\mathrm{CO}_{2}$ emissions. Additionally, the results show that carbon footprints are slightly higher than one, indicating that they are increasing with respect to final demand at a more than proportional rate. Therefore, the final demand increases may be considered an important factor in explaining emissions growth.

Similarly, the results show notable differences between countries. The values of these elasticities increase with the final demand per capita of countries, which is especially noted for the EU-27 sample. Those with lower final demand values register elasticities below one, while those with higher final demand values generally register elasticities above one, the latter being the EU-15 countries. Thus, the differences in the levels of final demand per capita between countries are making a difference to the carbon footprints generated among them. The underlying reasons open further research possibilities, for example, changes in consumer partnerships as countries get richer, or the energy intensity associated to the production of goods and services that shape the final demand. 


\section{ACKNOWLEDGMENTS}

The authors would like to express their gratitude for the financial support received from the ECO2014-56399-R Project of the Spanish Ministry of Economy and Competitiveness, and from the Chair of Energy and Environmental Economics of the Fundació Roger Torné. The authors would also like to thank Dr. Erik Dietzenbacher (University of Groningen) for his suggestions.

\section{REFERENCES}

Ahmed, K. and W. Long (2012) Environmental Kuznets Curve and Pakistan: An Empirical Analysis. Procedia Economics and Finance, 1, 4-13.

Aichele, R. and G.J. Felbermayr (2012) Kyoto and the Carbon Footprint of Nations. Journal of Environmental Economics and Management, 63, 336-354.

Al-Mulali, U., C. Weng-Wai, L. Sheau-Ting, and A.H. Mohammed (2015a) Investigating the Environmental Kuznets Curve (EKC) Hypothesis by Utilizing the Ecological Footprint as an Indicator of Environmental Degradation. Ecological Indicators, 48, 315-323.

Al-Mulali, U., B. Saboori and I. Ozturk (2015b) Investigating the Environmental Kuznets Curve Hypothesis in Vietnam. Energy Policy, 76, 123-131.

Andrew, R.M., S.J. Davis, and G. Peters (2013) Climate Policy and Dependence on Traded Carbon. Environmental Research Letters, 8, 034011(7pp).

Andrew, R.M. and G.P. Peters (2013) A Multi-Region Input-Output Table based on the Global Trade Analysis Project Database (GTAP-MRIO). Economic Systems Research 25, 99-121.

Arto, I., and E. Dietzenbacher (2014) Drivers of the Growth in Global Greenhouse Gas Emissions. Environmental Science \& Technology, 48, 5388-5394.

Cohen, C.A.M.J., M. Lenzen and R. Schaeffer (2005) Energy Requirements of Households in Brazil. Energy Policy, 33, 555-562.

Dietzenbacher, E., B. Los, R. Stehrer, M. Timmer, and G. De Vries (2013) The Construction of World Input-Output Tables in the WIOD Project. Economic Systems Research, 25, 71-98.

Dinda, S. (2004) Environmental Kuznets Curve Hypothesis: A Survey. Ecological Economics, 49, 431-455.

Fodha, M. and O. Zaghdoud (2009) Economic Growth and Pollutant Emissions in Tunisia: An Empirical Analysis of the Environmental Kuznets Curve. Energy Policy, 38, 11501156.

Friedl, B. and M. Getzner (2003) Determinants of $\mathrm{CO}_{2}$ Emissions in a Small Open Economy. Ecological Economics, 45, 133-148. 
Genty, A. (Ed) (2012) Final Database of Environmental Satellite Accounts: Technical Report on their Compilation, WIOD Deliverable 4.6 Documentation. http://www.wiod.org/publications/source_docs/Environmental_Sources.pdf

Greene, W. (2000) Econometric Analysis, $4^{\text {th }}$ Edition. New York (USA), Prentice Hall.

Grossman, G. and A. Krueger (1991) Environmental Impacts of a North American Free Trade Agreement. Working Paper WP3914. Cambridge (MA), National Bureau of Economic Research.

Halicioglu, F. (2009) An Econometric Study of $\mathrm{CO}_{2}$ Emissions, Energy Consumption, Income and Foreign Trade in Turkey. Energy Policy, 37, 1156-1164.

He, J. and P. Richard (2010) Environmental Kuznets Curve for $\mathrm{CO}_{2}$ in Canada. Ecological Economics, 1083-1093.

Hertwich, E.G. and G.P. Peters (2009) Carbon Footprint of Nations: A Global, Trade-Linked Analysis. Environmental Science \& Technology, 43, 6414-6420.

Heston, A., Summers, R. and Bettina, A. (2012) Penn World Table Version 7.1. Centre for International Comparisons of Production, Income and Prices at the University of Pennsylvania

Hoekstra, R., B. Michel and S. Suh (2016) The emission cost of international sourcing: Using Structural Decomposition Analysis to calculate the contribution of international sourcing to CO2-emission growth. Economic Systems Research, 28, 151-167

Hsiao, C. (2007) Panel Data Analysis-Advantages and Challenges. Test, 16(1), 1-22.

Hsiao, C., Mountain, D.C. and Ho-Illman, K. (1995) Bayesian Integration of End-Use Metering and Conditional Demand Analysis. Journal of Business and Economic Statistics, 13, 315-326.

Jalil, A. and M. Feridun (2011) The Impact of Growth, Energy and Financial Development on the Environment in China: A Cointegration Analysis. Energy Economics, 33, 284-291.

Jebli, M.B., S.B. Youssef and I. Ozturk (2016) Testing Environmental Kuznets Curve Hypothesis: The Role of Renewable and Non-Renewable Energy Consumption and Trade in OECD Countries. Ecological Indicators, 60, 824-831.

Kanemoto, K., D. Moran, M. Lenzen and A. Geschke (2014) International Trade Undermines National Emission Reduction Targets: New Evidence from Air Pollution. Global Environmental Change, 24, 52-59.

Lau, L.S., C.K. Choong and Y.K. Eng (2014) Investigation of the Environmental Kuznets Curve for Carbon Emissions in Malaysia: Do Foreign Direct Investment and Trade Matter? Energy Policy, 68, 490-497.

Leckie, G., R. French, C. Charlton and W. Browne (2014) Modeling Heterogeneous Variance-Covariance Components in Two-Level Models. Journal of Educational and Behavioral Statistics, 39, 307-332.

Lenzen, M. (1998) Energy and Greenhouse Gas Cost of Living for Australia during 1993/94. Energy, 23(6), 497-516.

Lenzen, M., M. Wier, C. Cohen, H. Hayami, S. Pachauri and R. Schaeffer (2006) A Comparative Multivariate Analysis of Household Energy Requirements in Australia, Brazil, Denmark, India and Japan. Energy, 31, 181-207.

Lenzen, M., K. Kanemoto, D. Moran and A. Geschke (2012) Mapping the structure of the world economy. Environmental Science \& Technology 46, 8374-8381. 
Lenzen, M., D. Moran, K. Kanemoto and A. Geschke (2013) Building Eora: A global multiregion input-output database at high country and sector resolution. Economic Systems Research 25, 20-49.

Luzzati, T. and M. Orsini (2009) Investigating the Energy-Environmental Kuznets Curve. Energy, 34, 291-300.

Malik, A. and J. Lan (2016) The role of outsourcing in driving global carbon emissions. Economic Systems Research, 28, 168-182.

Malik, A., J. Lan and M. Lenzen (2016) Trends in global greenhouse gas emissions from 1990 to 2010. Environmental Science \& Technology, 50, 4722-4730.

Meng, B., Y. Zhang and S. Inomata (2013) Compilation and application of IDE-JETRO's international Input-Output tables. Economic Systems Research 25, 122-142.

Menyah, K. and Y. Wolde-Rufael (2010) Energy Consumption, Pollutant Emissions and Economic Growth in South Africa. Energy Economics, 32, 1374-1382.

Narayan, P.K., and S. Narayan, (2010) Carbon Dioxide Emissions and Economic Growth: Panel Data Evidence from Developing Countries. Energy Policy, 38(1), 661-666.

Onafowora, O.A. and O. Owoye (2014) Bounds Testing Approach to Analysis of the Environment Kuznets Curve Hypothesis. Energy Economics, 44, 47-62.

Ozturk, I., and Acaravci, A. (2013) The Long-Run and Causal Analysis of Energy, Growth, Openness and Financial Development on Carbon Emissions in Turkey. Energy Economics, 36, 262-267.

Pablo-Romero, M.P. and A. Sánchez-Braza (2015) Productive Energy Use and Economic Growth: Energy, Physical and Human Capital Relationships. Energy Economics, 49, $420-429$.

Perrings, C. and A. Ansuategi (2000) Sustainability, Growth and Development. Journal of Economic Studies, 27, 19-54.

Pesaran, M.H. (2004) General Diagnostic Tests for Cross Section Dependence in Panels. Cambridge Working Papers in Economics No. 435. Faculty of Economics, University of Cambridge, Cambridge (USA).

Peters, G., R. Andrew and J. Lennox (2011) Constructing an environmentally-extended MultiRegion Input-Output table using the GTAP database. Economic Systems Research, 23, 131-152.

Peters, G. P., G. Marland, E.G. Hertwich, L. Saikku, A. Rautiainen and P.E. Kauppi (2009). Trade, Transport, and Sinks Extend the Carbon Dioxide Responsibility of Countries: An Editorial Essay. Climatic Change, 97(3-4), 379-388.

Peters, G.P., G. Marland, C. Le Quéré, T. Boden, J.G. Canadell and M.R. Raupach (2012) Rapid Growth in $\mathrm{CO}_{2}$ Emissions after the 2008-2009 Global Financial Crisis. Nature Climate Change, 2, 2-4.

Piaggio, M. and E. Padilla (2012) $\mathrm{CO}_{2}$ Emissions and Economic Activity: Heterogeneity Across Countries and Non-Stationary Series. Energy Policy, 46, 370-381.

Rabe-Hesketh, S. and A. Skrondal (2008) Multilevel and Longitudinal Modeling Using Stata. College Station (TX), Stata press. 
Rueda-Cantuche, J.M. (2012) 7 Comparisons of the European Carbon Footprint (2000-2006) from Three Different Perspectives within a Multi-regional Framework. In: V. Costantini. et al. (eds.) Hybrid Economic-environmental Accounts, 17. Oxford UK, Routledge, 125139.

Schandl, H., S Hatfield-Dodds, T. Wiedmann, A. Geschke, Y. Cai, J. West, ... and A. Owen (2016). Decoupling global environmental pressure and economic growth: scenarios for energy use, materials use and carbon emissions. Journal of Cleaner Production, 132, 4556.

Selden, T. and D. Song (1994) Environmental Quality and Development: Is There a Kuznets Curve for Air Pollution Emissions? Journal of Environmental Economics and Management; 27, 147-162.

Serrano, M. and E. Dietzenbacher (2010) Responsibility and Trade Emission Balances: An Evaluation of Approaches. Ecological Economics, 69, 2224-2232.

Song, T., T. Zheng, and L. Tong (2008) An Empirical Test of the Environmental Kuznets Curve in China: A Panel Cointegration Approach. China Economic Review, 19, 381-392.

Steckel, J.C., R.J. Brecha, M. Jakob, J. Strefler and G. Luderer (2013) Development without Energy? Assessing Future Scenarios of Energy Consumption in Developing Countries. Ecological Economics, 90, 53-67.

Tang, Q., Z. Wang, J. Xue, and X. Cong (2015) Input-Output Analysis of $\mathrm{CO}_{2}$ Emissions Embodied in International Trade and the Analysis of Geopolinomic Structure Implications. Energy and Environmental Engineering, 1, 231.

Timmer, M.P., E. Dietzenbacher, B. Los, R. Stehrer, and G.J. Vries (2015) An Illustrated User Guide to the World Input-Output Database: The Case of Global Automotive Production. Review of International Economics. 575-605.

Tukker, A., A. de Koning, R. Wood, T. Hawkins, S. Lutter, J. Acosta, J.M. Rueda Cantuche, M. Bouwmeester, J. Oosterhaven, T. Drosdowski and J. Kuenen (2013) EXIOPOL Development and Illustrative Analyses of a Detailed Global MR EE SUT/IOT. Economic Systems Research, 25, 50-70.

UNEP (2010) Assessing the Environmental Impacts of Consumption and Production: Priority Products and Materials, A Report of the Working Group on the Environmental Impacts of Products and Materials to the International Panel for Sustainable Resource Management. Hertwich, E., van der Voet, E., Suh, S., Tukker, A., Huijbregts M., Kazmierczyk, P., Lenzen, M., McNeely, J., Moriguchi, Y.

West B.T. and A.T. Galecki (2011) An Overview of Current software Procedures for Fitting Linear Mixed Models. The American Statistician, 65, 274-282.

Wiebe, K.S., M. Bruckner, S. Giljum and C. Lutz (2012) Calculating Energy-Related $\mathrm{CO}_{2}$ Emissions Embodied in International Trade Using a Global Input-Output Model. Economic Systems Research, 24, 113-139.

Wiedmann, T. (2009) A First Empirical Comparison of Energy Footprints Embodied in Trade-MRIO versus PLUM. Ecological Economics, 68, 1975-1990.

Wiedmann, T., R. Wood, J.C. Minx, M. Lenzen, D. Guan and R. Harris (2010) A Carbon Footprint Time Series of the UK-Results from a Multi-Region Input-Output Model. Economic Systems Research, 22, 19-42.

Wier, M., M. Lenzen, J. Munksgaard and S. Smed (2001) Effects of household consumption patterns on CO2 requirements. Economic Systems Research, 13, 259-274. 
WIOD (2015) World Input-Output database. WIOD, European Commission www.wiod.org (Last accessed October 2015).

Wooldridge, J.M. (2002). Econometric Analysis of Cross Section and Panel Data. Cambridge (USA), MIT Press.

$\mathrm{Xu}, \mathrm{Y}$. and E. Dietzenbacher (2014) A Structural Decomposition Analysis of the Emissions Embodied in Trade. Ecological Economics, 101, 10-20.

Zhang, B., Z.M. Chen, X.H. Xia, X.Y. Xu, and Y.B. Chen (2013) The Impact of Domestic Trade on China's Regional Energy Uses: A Multi-Regional Input-Output Modelling. Energy Policy,63, 1169-1181. 


\section{Appendix}

The general specification model for testing these different EKCs is expressed as follows:

$$
E_{i t}=A_{i t}+\beta_{1} Y_{i t}+\beta_{2} Y_{i t}^{2}+\beta_{3} Y_{i t}^{3}+e_{i t}
$$

where $E$ is a measure of emissions per capita in logarithms, in this case carbon footprints, $Y$ is the independent variable of final demand per capita in logarithms, $A$ represents the sum of the time effect and country or individual effect and $i$ and $t$ denote countries and years, respectively. Finally, $e$ is a random error term.

To estimate the functions properly, and avoid spurious estimates, the data were converted to deviations from the geometric mean of the sample and transformed into first differences. Using italics to indicate these deviations, and the symbol $\Delta$ to indicate first differences, it is possible to rewrite [A.1], as follows,

$$
\Delta \bar{E}_{i t}=\Delta \bar{A}_{i t}+\beta_{1} \Delta \bar{Y}_{i t}+\beta_{2} \Delta \bar{Y}_{i t}^{2}+\beta_{3} \Delta \bar{Y}_{i t}^{3}+e_{i t}
$$

where $\Delta \bar{A}_{i t}=\delta_{\mathrm{t}}$.

The elasticity of $E$ with respect to $Y$ may be calculated for each year and country from [A.2], as follows:

$$
e l a_{i t}=\beta_{1}+2 \beta_{2} \bar{Y}_{i t}+3 \beta_{3} \bar{Y}_{i t}^{2}
$$

Although expression [A.3] allows the behavior of different countries to be assessed, the difference is exclusively linked to the final demand levels of the different countries, as the estimated coefficients $\beta_{1}, \beta_{2}$ and $\beta_{3}$ are constants. Thus, when estimating this function it is useful to take into account the heterogeneity that exists, or may exist, between countries. This means that $\beta$ coefficients may vary between countries.

In order to take into account the heterogeneity between countries, two options may be considered. The first is to test the EKC at national level and the second option is to take the 
whole panel data sample, which include all countries, and allow the coefficients to not be constant, but to vary.

Following the second option, equation [A.1] may be defined as an equations system as:

$$
\begin{aligned}
& E_{i t}=A_{i t}+\beta_{1} Y_{i t}+\beta_{2} Y_{i t}^{2}+\beta_{3} Y_{i t}^{3}+e_{i t} \\
& \beta_{1}=\gamma_{1}+\sum_{n} \gamma_{1 n} Z_{i t} \\
& \beta_{2}=\gamma_{2}+\sum_{n} \gamma_{2 n} Z_{i t} \\
& \beta_{3}=\gamma_{3}+\sum_{n} \gamma_{3 n} Z_{i t}
\end{aligned}
$$

where $Z$ is a set of control variables that may affect the relationships between final demand and carbon footprints. In this current study, structure and imports were included.

With the aim of symplifying the analysis, and taking into account the lack of significance of coeficients of the $Z$ control variables in $\beta_{2}$ and $\beta_{3}$ in the first estimate results, the equations system [A.4] was reduced to

$$
\begin{aligned}
& E_{i t}=A_{i t}+\beta_{1} Y_{i t}+\beta_{2} Y_{i t}^{2}+\beta_{3} Y_{i t}^{3}+e_{i t} \\
& \beta_{1}=\gamma_{1}+\sum_{n} \gamma_{1 n} Z_{i t}
\end{aligned}
$$

Expresing this equations system in a unique equation, the expresion [A.6] is obtained.

$$
E_{i t}=A_{i t}+\gamma_{1} Y_{i t}+\gamma_{1 s} S_{i t} Y_{i t}+\gamma_{1 Q} Q_{i t} Y_{i t}+\beta_{2} Y_{i t}^{2}+\beta_{3} Y_{i t}^{3}+e_{i t}
$$

where both $Z$ variables used are defined as $S$ and $Q$.

To estimate the functions properly and avoid spurious estimates, the data are converted, as before, to deviations from the geometric mean of the sample, and transformed into first differences. Using italics to indicate these deviations, and the symbol $\Delta$ to indicate first differences, it is possible to rewrite [A.6], as follows

$$
\Delta \bar{E}_{i t}=\Delta \bar{A}_{i t}+\gamma_{i} \Delta \bar{Y}_{i t}+\gamma_{1 s} \Delta \overline{S_{i t} Y_{i t}}+\gamma_{1 Q} \Delta \overline{Q_{i t} Y_{i t}}+\beta_{2} \Delta \bar{Y}_{i t}^{2}+\beta_{3} \Delta \bar{Y}_{i t}^{3}+e_{i t}
$$


As an alternative to the defined model, in which the $\beta_{1}$ coefficient value depends on $S$ and $Q$, it is possible to define a more flexible model by including a radom term in the $\beta_{1}$ coefficient, in which the coeficient is considered as a latent variable.

Therefore, $\beta_{1}$ may be defined as

$$
\beta_{1}=b_{1 i}+\sum_{n} \gamma_{1 n} Z_{i t}
$$

where

$b_{1 i}=\gamma_{1}+\mu_{1 i}$

and where $\mu$ represents the random effects for the individual observations, allowing that $\beta_{1}$ varies randomly across countries.

Thus, equation [A.7] may be expressed as

$\Delta \bar{E}_{i t}=\Delta \bar{A}_{i t}+\gamma_{i} \Delta \bar{Y}_{i t}+\gamma_{1 s} \Delta \overline{S_{i t} Y_{i t}}+\gamma_{1 Q} \Delta \overline{Q_{i t} Y_{i t}}+\mu_{1 i} \Delta \bar{Y}_{i t}+\beta_{2} \Delta \bar{Y}_{i t}^{2}+\beta_{3} \Delta \bar{Y}_{i t}^{3}+e_{i t}$

With the aim of making the equation even more flexible, $\beta_{2}$ may be defined as

$$
\beta_{2 i}=\gamma_{2}+\mu_{2 i}
$$

Thus the equation to be estimated may be expressed as [A.11]

$$
\Delta \bar{E}_{i t}=\Delta \bar{A}_{i t}+\gamma_{i} \Delta \bar{Y}_{i t}+\gamma_{1 s} \Delta \overline{S_{i t} Y_{i t}}+\gamma_{1 Q} \Delta \overline{Q_{i t} Y_{i t}}+\mu_{1 i} \Delta \bar{Y}_{i t}+\gamma_{2} \Delta \bar{Y}_{i t}^{2}+\mu_{2 i} \Delta \bar{Y}_{i t}^{2}+\beta_{3} \Delta \bar{Y}_{i t}^{3}+e_{i t}
$$

where [A.9] and [A.11] may be estimated by using multilevel mixed-effects models.

From [A.11], the elasticity of $E$ with respect to $Y$ may be calculated for each year and country, as follows:

$$
e l a_{i t}=\gamma_{i t}+\mu_{1 i}+\gamma_{1 s} \bar{S}_{i t}+\gamma_{1 Q} \bar{Q}_{i t}+2 \gamma_{2} \bar{Y}_{i t}+2 \mu_{2 i} \bar{Y}_{i t}+3 \beta_{3} \bar{Y}_{i t}^{2}
$$

Equation [A.12] shows that the elasticity of $E$ with respect to $Y$ is much more flexible than that obtained in [A.3], values being dependent on total demand level and other factors. 